\title{
THAT ELUSIVE ELASTICITY: A LONG-PANEL APPROACH TO ESTIMATING THE CAPITAL-LABOR SUBSTITUTION ElASTICITY
}

\author{
ROBERT S. CHIRINKO \\ STEVEN M. FAZZARI \\ ANDREW P. MEYER
}

CESIFO WORKING PAPER NO. 1240

CATEGORY 1: PUBlic FinANCE

JULY 2004

Presented at CeSifo Area Conference on Public Sector Economics, MAY 2004 


\title{
THAT ELUSIVE ELASTICITY: A LONG-PANEL APPROACH TO ESTIMATING THE CAPITAL-LABOR SUBSTITUTION ELASTICITY
}

\begin{abstract}
The elasticity of substitution between capital and labor features prominently in several areas of economic research. However, a consensus estimate remains elusive. We develop an estimation strategy that filters panel data in an original way and avoids several pitfalls difficult-to-specify dynamics, transitory time-series variation, and positively sloped supply schedules - inherent in investment equations that can bias the estimated elasticity. Results are based on an extensive panel containing 1,860 manufacturing and non-manufacturing firms. Our model generates a precisely estimated elasticity of approximately 0.40 . The method developed here may prove useful in estimating other structural parameters from panel datasets.
\end{abstract}

JEL Code: H32, E22.

\author{
Robert S. Chirinko \\ Dept. of Economics \\ Emory University \\ Atlanta, Georgia 30322-2240 \\ USA \\ rchirin@emory.edu
}

\author{
Steven M. Fazzari \\ Dept. of Economics \\ Washington University \\ St. Louis, Missouri 63130 \\ USA \\ fazz@economics.wustl.edu
}

\author{
Andrew P. Meyer \\ Federal Reserve Bank of St. Louis \\ St. Louis, Missouri 63166-0442 \\ USA \\ ameyer@stls.frb.org
}

We thank Hashem Dezhbakhsh, Harry Huizinga, Daniel Levy, Doug Meade, James Morley, Werner Roeger, Julio Rotemberg, Lawrence Summers, Giovanni Urga, Philip Vermuellen, Kenneth West, an anonymous referee, and seminar participants at the 10th International Conference On Panel Data (Berlin), the Center for Economic Studies (Munich), the Centro de Investigacion y Docencia Economicas (Mexico City), Emory University, the European Central Bank, the European Commission, the University of Illinois (Chicago) and the University of Missouri for comments and suggestions, and Kate von Koss for preparing Figure 1. The views expressed here do not necessarily reflect those of the Federal Reserve Bank of St. Louis nor the Federal Reserve System. All errors, omissions, and conclusions remain the sole responsibility of the authors. 


\section{Table Of Contents}

Abstract

I. Introduction

II. Estimation Strategy

III. The Panel Dataset

IV. Empirical Results
A. Cross-Sectional Variation in Growth Rates
B. OLS Estimates
C. Measurement Error
D. An Alternative Interpretation
E. IV Estimates
F. Split-Sample Estimates
G. Comparison to Other Approaches

V. Summary and Conclusions

References

Appendix A: Trending Variables

Appendix B: The Replacement Value of Capital

Appendix C: Short-Run Frictions and Measurement Error

Tables

Figure 1: The $\tau$-Interval Definition

Figure 2: Normalized Spectra for the Interval-Difference $(\mathrm{I}(\omega))$ and YearDifference $(\mathrm{Y}(\omega))$ Estimators 


\section{That Elusive Elasticity: A Long-Panel Approach To Estimating The Capital-Labor Substitution Elasticity}

\section{Introduction}

Estimating the elasticity of substitution between capital and labor has been an important topic on the quantitative research agenda for decades. This elasticity, $\sigma$, features prominently in several areas of economic research. The validity of various growth theories depends on the value of $\sigma$. Policymakers frequently alter price incentives for capital accumulation, and $\sigma$ is a key element determining policy effectiveness and the resulting welfare changes. Although this elasticity has been the subject of an enormous number of empirical studies, a consensus estimate remains elusive.

The range of estimated values for $\sigma$ corresponds to an equally wide range of implications for growth models. Values of $\sigma$ near or below unity cast doubt on the validity of the Solow growth model as conventionally formulated. Mankiw (1995, p. 287) presents a formula for computing the impact of $\sigma$ on the difference in rates of return on capital between rich and poor countries implied by the Solow model. When $\sigma=4.0$, the implied rate of return difference is only 3 percentage points. ${ }^{1}$ However, as $\sigma$ is lowered to 1.0 or 0.5 , the implied differences become implausibly large, rising to 32 and 100 percentage points, respectively. In the Solow growth model, Klump and Preissler (2000) show that the substitution elasticity is negatively related to the speed of convergence toward the steady-state (if the economy has overaccumulated capital) and positively related to steady-state per capita output. ${ }^{2}$ If $\sigma$ exceeds unity, long-run growth is possible even without any technological progress (Pitchford, 1960; Barro and Sala-i-Martin, 1995).

Acemoglu (2001) shows that the relative contributions of technological change and factor accumulation in accounting for long-run growth depend on $\sigma$, which has further implications for the importance of biased technological change and the movement of factor shares. ${ }^{3}$

\footnotetext{
${ }^{1}$ These computations are based on the assumptions of a 10 percent return in the rich country and a capital elasticity in production of $2 / 3$.

${ }^{2}$ However, the latter result is not robust; in a Diamond overlapping generations model, Miyagiwa and Papageorgiou (2003) show that $\sigma$ and steady-state per capita output are negatively related (provided $\sigma$ is sufficiently large).

${ }^{3}$ Furthermore, in the original article introducing the CES production function, Arrow, Chenery, Minhas, and Solow (1961) note that the impact of factor endowments on international trade and the variation of relative income shares depend on the value of this elasticity.
} 
The substitution elasticity is also essential for evaluating the impact of tax policies. In a simplified version of the Ballard, Fullerton, Shoven, and Whalley (1985) computational general equilibrium (CGE) model, the change in welfare from equalizing capital tax rates across industries is 70 percent larger when the elasticity rises from 0.50 to 1.00. Similarly, Engen, Gravelle, and Smetters (1997, Table 5) show that, when the income tax is replaced by a consumption tax, the increase in steady-state net output is 79 percent higher when the elasticity of 0.50 is replaced by a value of unity. Results from the two-country model of Roeger, Veld, and Woehrmann (2000) are also sensitive to whether the elasticity is 0.50 or 1.00; a one percentage point cut in one country's corporate tax rate leads to a 70 percent larger increase in combined consumption with the larger elasticity. Fox and Fullerton (1991) find that, in CGE models, estimated welfare gains from tax initiatives depend much more on this elasticity than on the complex features and detailed disaggregation found in many simulation models. Starting with the seminal analysis of Harberger $(1959,1962)$, the substitution elasticity between capital and labor, equivalent to the user cost elasticity of capital under a CES production technology, is central to assessing policy impacts.

Despite the substantial research energies devoted to estimating this elasticity, a consensus value remains elusive. ${ }^{4}$ For example, in the Joint Committee On Taxation's (1997, Table 6) study of nine different tax models, elasticities range from 0.20 to 1.00 . The wide range of estimated elasticities reported in the literature may be attributed to a common source. Most econometric studies rely on quarterly or annual time-series variation in investment data to identify the elasticity. Three biases may result that weigh more or less heavily in different studies. First, the specification of an investment equation requires assumptions about dynamics. While economic theory is highly informative about the determinants of the demand for the stock of capital, it is relatively silent about the demand for the flow of investment. Misspecified dynamics can bias estimates of the elasticity (Summers, 1988). Of particular importance are the nature of adjustment costs and the role of financing constraints, which have received a great deal of attention in recent years and whose effects on investment spending remain controversial. ${ }^{5}$ Second, coefficient estimates from investment regressions may be

\footnotetext{
${ }^{4}$ See Chirinko (1993), Hassett and Hubbard (1997), and Mairesse, Hall, and Mulkay (1999) for surveys of the empirical literature.

${ }^{5}$ Regarding adjustment costs, see the surveys by Hamermesh and Pfann (1996) and Caballero (1999). Regarding financing constraints, see the survey by Hubbard (1998) and the controversy
} 
biased if the time-series variation of investment spending largely reflects adjustments to transitory shocks and firms respond less to transitory than permanent variation because of adjustment costs. An elasticity estimated with time-series data at quarterly or annual frequencies will tend to be lower than the "true" long-run elasticity. ${ }^{6}$ Third, if the supply curve of investment is upward sloping, as is more likely in the short to medium-run, studies incorrectly maintaining a perfectly elastic supply schedule will tend to understate demand elasticities (Goolsbee, 1998). ${ }^{7}$ While the misspecification of dynamics has an indeterminate effect, the estimated elasticity will be biased toward zero by transitory time-series variation and positively sloped supply schedules.

These potential problems all stem from a common source -- the use of investment data as the measure of capital formation. We avoid these problems by developing an approach that relies directly on capital stock data and exploits in an original way the substantial information available from panel data. We focus on the first-order condition relating the long-run desired capital stock $\left(\mathrm{K}^{*}\right)$ to the longrun desired values of output $\left(\mathrm{Y}^{*}\right)$ and the user cost $\left(\mathrm{C}^{*}\right)$. This specification underlies virtually all investment studies since Jorgenson's (1963) path-breaking work on the neoclassical model of capital accumulation and can be represented as follows:

$$
\mathrm{K}^{*}=\underset{+}{\mathrm{G}}\left[\mathrm{Y}^{*}, \mathrm{C}^{*}\right]
$$

The difficulty with estimating (1) is that the desired values are not readily observable. We use panel data, long in the time dimension, to estimate the variables in (1) as time-averages within firms. With empirical counterparts to $\mathrm{K}^{*}$, $\mathrm{Y}^{*}$, and $\mathrm{C}^{*}$ defined, it is straightforward to estimate G[.]. To account for firm effects and productivity shocks, we specify equation (1) in growth rates. Our econometric model regresses the growth rate of the capital stock on the growth rates of the user cost and output across firms. Cross-sectional variation provides identification. This relatively simple, yet fully rigorous, approach estimates

in Kaplan and Zingales (1997, 2000) and the reply by Fazzari, Hubbard, and Petersen (2000). Chirinko, Fazzari, and Meyer (1999) show that excluding cash flow (a variable typically included to capture financing constraints) from an investment equation using annual data biases upward the estimated user cost elasticity.

${ }^{6}$ This point has been noted by, among others, Eisner (1967), Lucas (1969), Berndt (1976), Shapiro (1986b), and Kiyotaki and West (1996).

${ }^{7}$ This conclusion has been challenged by Hassett and Hubbard (1998) and Whelan (1999). 
technology parameters immune to the biases discussed above.

Our study proceeds as follows. Section II introduces the estimation strategy. The econometric equation is derived from the firm's profit-maximization problem, and long-run values of the variables entering the regression equation are measured as time-averages. Our estimation strategy accounts for a variety of productivity shocks, omitted variables, and firm fixed effects, and uses panel data in a way that differs substantially from prior panel studies. We demonstrate with spectral analysis how our estimator places relatively more weight on low frequency movements than the traditional investment model. Section III discusses the panel dataset containing, 1,860 firms for the period 1972 to 1991, and the construction of the variables. Section IV presents our OLS and IV results. Both techniques yield similar estimates of the substitution elasticity of approximately 0.40 . This estimate is higher than the elasticity of 0.25 reported by Chirinko, Fazzari, and Meyer (1999) based on the same dataset but using an investment model. Thus, the three problems affecting investment equations -- difficult-to-specify dynamics, transitory time-series variation, and positively sloped supply schedules -- impart a discernible bias toward zero. Nonetheless, the elasticity remains far from unity, the value defining the frequently used Cobb-Douglas production function and determining the cut-off at which tax incentives become cost effective (in a static sense). Section IV also assesses the importance of measurement error, offers an alternative interpretation of our estimator in terms of a low-pass filter, examines the sensitivity of the estimates to various subsets of the sample, and compares our approach to related work with panel data. Section V offers a summary and conclusions.

\section{Estimation Strategy}

Our econometric model follows directly from the behavior of a firm that maximizes its discounted flow of profits over an infinite horizon. We analyze the firm's choices in long-run equilibrium, thus eliminating the need to model adjustment costs, delivery lags, vintage effects, and expectations. Under these assumptions, the firm always produces its long-run desired level of output with its long-run desired mix of inputs. The critical consequence is that the firm's dynamic optimization problem is transformed into a static problem. To determine the firm's demand for capital, we need only calculate the marginal product of capital evaluated at the long-run levels of inputs and output.

We assume that production possibilities are described by the following CES technology, 


$$
\mathrm{Y}_{\mathrm{f}, \mathrm{t}}^{*}=\left\{\omega\left(\mathrm{K}_{\mathrm{f}, \mathrm{t}}^{*}{ }^{[(\sigma-1) / \sigma]}\right)+(1-\omega)\left(\mathrm{X}_{\mathrm{f}, \mathrm{t}}^{*[(\sigma-1) / \sigma]}\right)\right\}^{[\eta \sigma /(\sigma-1)]} \mathrm{U}_{\mathrm{f}, \mathrm{t}}
$$

where $\mathrm{Y}_{\mathrm{f}, \mathrm{t}}^{*}$ is long-run desired real output for firm $\mathrm{f}$ at time $\mathrm{t}, \mathrm{K}_{\mathrm{ft}, \mathrm{t}}^{*}$ is the long-run desired real capital stock, $\mathrm{X}_{\mathrm{f}, \mathrm{t}}^{*}$ is the long-run desired level of all other factors of production, and $\mathrm{U}_{\mathrm{f}, \mathrm{t}}$ represents a stochastic productivity shock. ${ }^{8}$ An attractive feature of the CES technology is that it depends on only three parameters characterizing returns to scale $(\eta)$, the distribution of factor returns $(\omega)$ and, of particular importance for this study, substitution possibilities between the factors of production $(\sigma)$. The CES function is strongly separable, and it can be expanded to include many additional factors of production (e.g., intangible capital) without affecting the estimating equation derived below. This feature gives the CES specification an important advantage relative to other technologies that allow for a more general pattern of substitution possibilities (e.g., the translog, minflexLaurent). Our approach does not require price and quantity data on the other factors of production (with limited availability and reliability at the firm level) to recover the key parameter of interest.

Differentiating (2) with respect to capital, we obtain the following relation for the marginal product of capital $\left(\partial \mathrm{Y}_{\mathrm{f}, \mathrm{t}}^{*} / \partial \mathrm{K}_{\mathrm{f}, \mathrm{t}}^{*}\right)$,

$$
\partial \mathrm{Y}_{\mathrm{f}, \mathrm{t}}^{*} / \partial \mathrm{K}_{\mathrm{f}, \mathrm{t}}^{*}=(\eta \omega) \mathrm{Y}_{\mathrm{f}, \mathrm{t}}^{*[1+(1-\sigma) / \sigma \eta]} \mathrm{K}_{\mathrm{f}, \mathrm{t}}^{*-[1 / \sigma]} \mathrm{U}_{\mathrm{f}, \mathrm{t}}^{[(\sigma-1) / \sigma \eta]} .
$$

Profit-maximization implies that this marginal product of capital equals the Jorgensonian user cost of capital $\left(\mathrm{C}_{\mathrm{f}, \mathrm{t}}^{*}\right)$, which combines interest, depreciation, and tax rates with relative prices (an exact specification of the user cost is deferred to Section III). Setting $\partial \mathrm{Y}_{\mathrm{f}, \mathrm{t}}^{*} / \partial \mathrm{K}_{\mathrm{f}, \mathrm{t}}^{*}$ equal to $\mathrm{C}_{\mathrm{f}, \mathrm{t}}^{*}$ and rearranging (3), we obtain the following expression for the long-run desired capital stock,

$$
\begin{aligned}
\mathrm{K}_{\mathrm{f}, \mathrm{t}}^{*}= & \Psi \mathrm{C}_{\mathrm{f}, \mathrm{t}}^{*[\alpha]} \mathrm{Y}_{\mathrm{f}, \mathrm{t}}^{*[\beta]} \mathrm{U}_{\mathrm{f}, \mathrm{t}}^{[\zeta]}, \\
\Psi & =(\eta \omega)^{\sigma}, \\
\alpha & =-\sigma, \\
\beta & =(\sigma \eta+1-\sigma) / \eta, \\
\zeta & =(\sigma-1) / \eta .
\end{aligned}
$$

Note that, with a CES production function, the user cost elasticity of capital is

\footnotetext{
${ }^{8}$ The limiting value of (2) as $\sigma \rightarrow 1$ is the Cobb-Douglas production function under the additional assumption that $\eta=1$.
} 
equivalent to the substitution elasticity between capital and other inputs (multiplied by minus one).

The central difficulty with estimating (4) is the that the long-run values are not observed. Most previous research addresses this problem by differencing the $\log$ of (4) to obtain an equation for investment. As discussed in the Introduction, however, this approach relies on the modeling challenges associated with investment data, and may therefore generate biased estimates. To avoid these potential problems, we measure the capital stock directly and then estimate the long-run desired levels of capital, output, and the user cost as time averages over several years. We refer to the years over which an average is computed as an interval. As shown in Figure 1 for a representative variable $W_{f, t}\left(W_{f, t}=\left\{K_{f, t}, Y_{f, t}\right.\right.$, $\left.\mathrm{C}_{\mathrm{f}, \mathrm{t}}\right\}$ ), we divide our sample into three intervals indexed by a $\tau$ subscript, $\tau=0,1,2$. The intervals are 1972-1977 $(\tau=0), 1978-1984(\tau=1)$, and 1985-1991 $(\tau=2)$. We assume that $\mathrm{W}_{\mathrm{f}, \mathrm{t}}^{*}$ equals $\mathrm{W}_{\mathrm{f}, \tau}$, where the latter is the mean of $\mathrm{W}_{\mathrm{f}, \mathrm{t}}$ over an interval. As we will discuss below, the $\tau=1$ and $\tau=2$ intervals are used for parameter estimation; the $\tau=0$ interval is used only to form instruments and define classifications that split the sample.

With the variables in (4) defined in terms of the $\tau=1$ and $\tau=2$ intervals, we take logs, and obtain the following equation,

$$
\begin{aligned}
& \mathrm{k}_{\mathrm{f}, \tau}=\alpha \mathrm{c}_{\mathrm{f}, \tau}+\beta \mathrm{y}_{\mathrm{f}, \tau}+\psi-\mathrm{u}_{\mathrm{f}, \tau}, \quad \tau=1,2 . \\
& \mathrm{k}_{\mathrm{f}, \tau}=\ln \left[\mathrm{K}_{\mathrm{f}, \tau}\right]=\ln \left[\mathrm{K}_{\mathrm{f}, \mathrm{t}}^{*}\right], \\
& \mathrm{c}_{\mathrm{f}, \tau}=\ln \left[\mathrm{C}_{\mathrm{f}, \tau}\right]=\ln \left[\mathrm{C}_{\mathrm{f}, \mathrm{t}}\right] \\
& \mathrm{y}_{\mathrm{f}, \tau}=\ln \left[\mathrm{Y}_{\mathrm{f}, \tau}\right]=\ln \left[\mathrm{Y}_{\mathrm{f}, \mathrm{t}}^{*}\right], \\
& \psi=\ln [\Psi],
\end{aligned}
$$

where $u_{f, \tau}$ is an error term that follows directly from the technology and represents productivity shocks. We model productivity shocks as follows,

$$
\mathrm{u}_{\mathrm{f}, \tau}=\zeta\left[\mathrm{v}_{\mathrm{f}}+\mathrm{v}_{\mathrm{i}}+\mathrm{w}_{\tau}+\mathrm{w}_{\mathrm{i}, \tau}+\mathrm{w}_{\mathrm{f}, \tau}\right] .
$$

The productivity shock is decomposed into firm-specific $\left(\mathrm{v}_{\mathrm{f}}\right)$ and industry-specific $\left(\mathrm{v}_{\mathrm{i}}\right)$ components, as well as components that vary over the $\tau$ intervals, $\mathrm{w}_{\tau}, \mathrm{w}_{\mathrm{i}, \tau}$ and $\mathrm{W}_{\mathrm{f}, \tau}$. With this error structure, estimates can be obtained by differencing (5) and (6) between the $\tau$ intervals, 
Figure 1: The $\tau$-Interval Definition

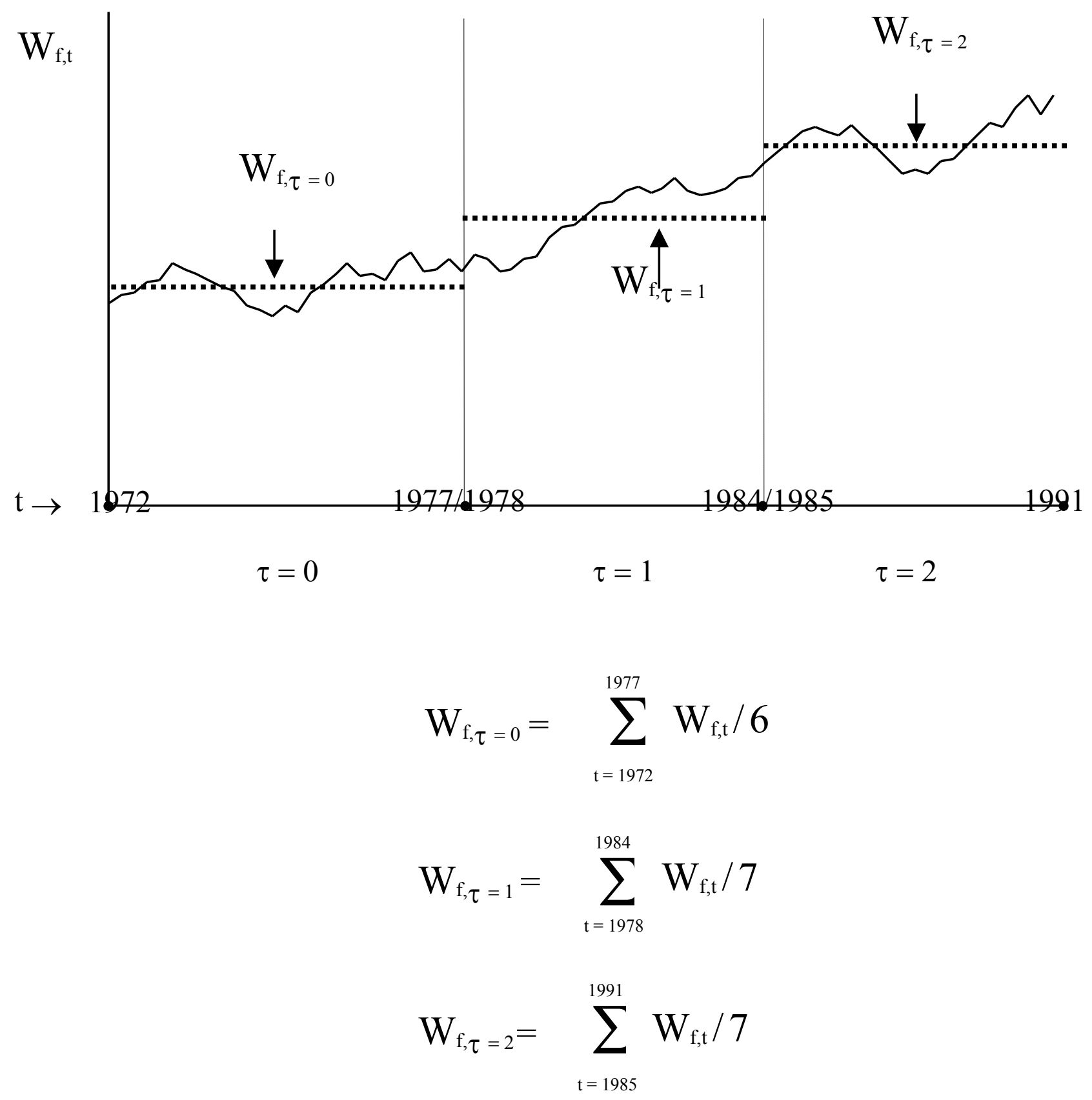




$$
\begin{aligned}
& \Delta \mathrm{k}_{\mathrm{f}, \tau}= \alpha \Delta \mathrm{c}_{\mathrm{f}, \tau}+\beta \Delta \mathrm{y}_{\mathrm{f}, \tau}+\Delta \psi-\Delta \mathrm{u}_{\mathrm{f}, \tau}, \\
& \Delta \mathrm{k}_{\mathrm{f}}=-\sigma \Delta \mathrm{c}_{\mathrm{f}}+\beta \Delta \mathrm{y}_{\mathrm{f}}-\gamma-\lambda_{\mathrm{i}}-\Delta \mathrm{w}_{\mathrm{f} .} . \\
& \sigma \quad=-\alpha, \\
& \eta \quad=(1-\sigma) /(\beta-\sigma), \\
& \gamma \quad=\zeta \Delta \mathrm{w}_{\tau}, \\
& \lambda_{\mathrm{i}} \quad=\zeta \Delta \mathrm{w}_{\mathrm{i}, \tau}, \\
& \Delta \mathrm{w}_{\mathrm{f}}=\Delta \mathrm{w}_{\mathrm{f}, \tau} .
\end{aligned}
$$

Because there are only two intervals, first-differencing eliminates the temporal dimension to the model, and $\tau$ subscripts have been omitted in the final equation. Consequently, the parameters are estimated in a cross-section regression. Fixed firm and industry effects are eliminated by differencing, and fixed interval effects (notably, biased technical change) are captured by the constant $(\gamma)$. Industry effects that vary across intervals are captured by industry dummies $\left(\lambda_{\mathrm{i}}\right)$.

Equation (7) is the basis for our estimation; it relates long-run growth in the capital stock to long-run growth in the user cost and output across firms. Crosssectional variation in the data identifies the parameters. Of course, the capital and output growth variables have cross-sectional variation. The user cost consists of three multiplicative terms - the relative price of capital to output, tax adjustments, and the opportunity cost of holding depreciating capital. The growth in the relative price and tax terms vary substantially across firms because of differences in the asset composition of firms' capital stock. For example, the relative price of capital for industries that use high-tech equipment declines more than the relative price for low-tech industries. This variation allows us to estimate the parameter of central interest in this study, the elasticity of the capital stock with respect to its user costs, $\sigma$. Additionally, we can recover the returns to scale elasticity, $\eta$, as a non-linear combination of the estimated $\sigma$ and $\beta$ parameters.

In contrast with prior studies that use investment data, our estimation strategy emphasizes low frequency variation. We estimate the long-run values of the regression variables by taking averages over several years (intervals), and then difference the data to control for a variety of firm and industry effects. This "interval-difference estimator" contrasts with the standard investment regression derived by differencing untransformed annual data, which we refer to as "the yeardifference estimator." Because it averages over several years, the intervaldifference estimator places substantially more weight on the lower frequencies in 
the data. To see this point more rigorously, it is instructive to interpret both estimators in the frequency domain. The spectra for the interval-difference and year-difference estimators are plotted in Figure 2. These spectra are normalized so that the area under each curve equals unity, and they should be interpreted relative to each other for any arbitrary input series. ${ }^{9}$ Figure 2 clearly demonstrates that the lower frequencies receive much more weight for the interval-difference estimator $(\mathrm{I}(\omega))$ relative to the year-difference estimator $(\mathrm{Y}(\omega))$. Thus our interval-difference estimator emphasizes low frequency variation that will lead to better estimates of $\sigma$.

Figure 2: Normalized Spectra For The Interval-Difference (I(w))

And Year-Difference $(Y(w))$ Estimators

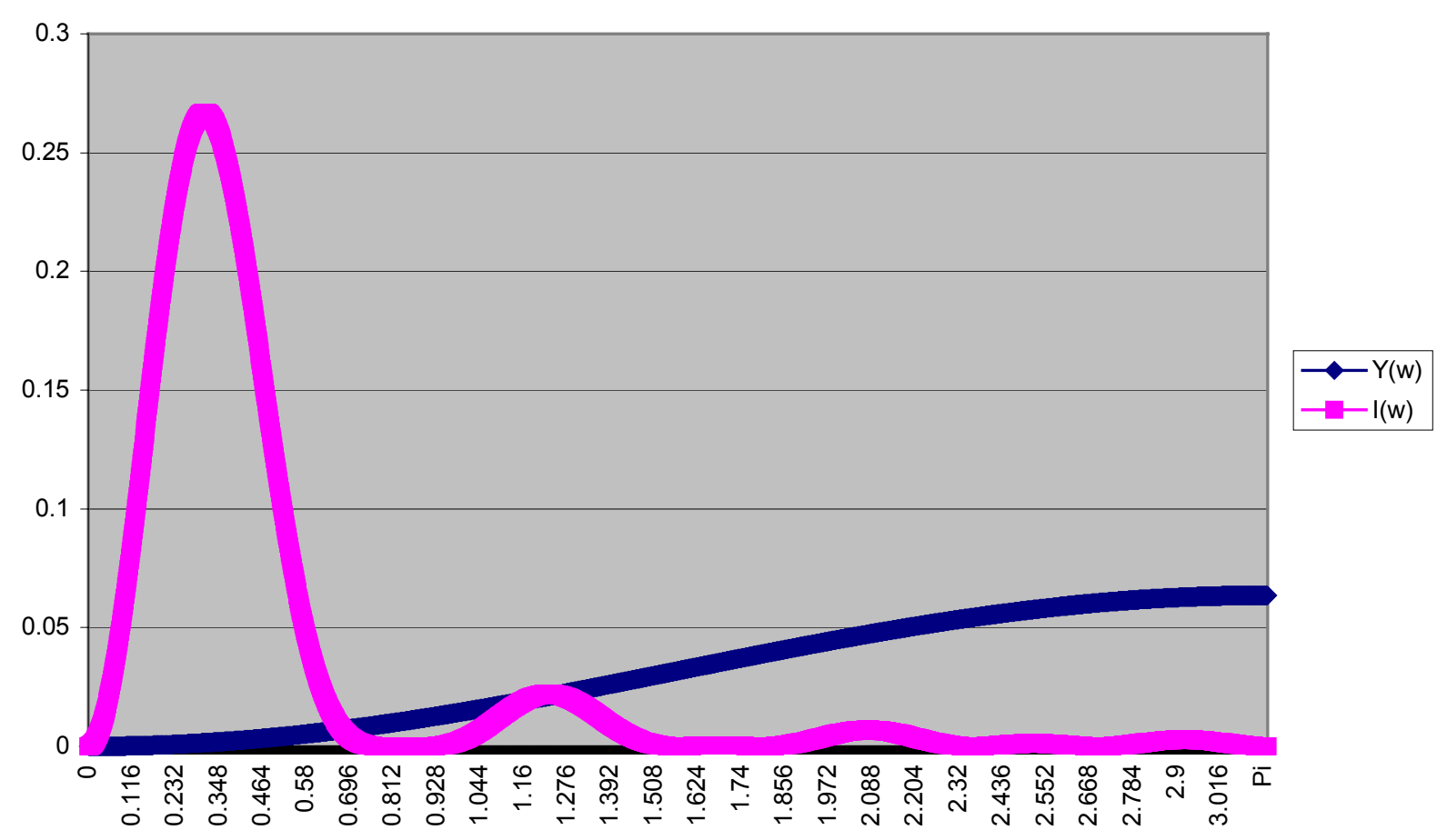

${ }^{9}$ We rely on the fundamental result from spectral analysis that the spectrum of a transformed series (the interval-difference or year-difference series) is the product of the spectrum of the input series (e.g., the capital/output ratio) and a nonnegative scalar that depends on the frequency, $\omega$. Following the development in Sargent (1979, Chapter XI) and using a first-order approximation for the log of a variable, the scalars for the interval-difference $(\mathrm{I}(\omega))$ and yeardifference $(\mathrm{Y}(\omega))$ series are as follows:

$\mathrm{I}(\omega)=(1 / 7)^{2} *(1-\operatorname{COS}(7 \omega)) * 2 *(1-\operatorname{COS}(2 * 4 * \omega)) /(1-\operatorname{COS}(\omega))$ (for an interval of seven years) and $\mathrm{Y}(\omega)=2 *(1-\operatorname{COS}(\omega))$ for $\omega \varepsilon[0, \pi]$. These are the functions plotted in figure 2 . 
Consistency of the OLS parameter estimates depends on the relation between the stochastic element, $\Delta \mathrm{w}_{\mathrm{f}}$, and the regressors, especially $\Delta \mathrm{y}_{\mathrm{f}}$. This correlation is not likely to be a problem for two reasons. First, $\Delta \mathrm{w}_{\mathrm{f}}$ is that part of the productivity shock that remains after accounting for all fixed and industry effects. Major technological changes (e.g. telecommunications, computing, the internet) are likely to have their largest effects on all firms (captured by $\gamma$ ) or on all firms in an industry (captured by $\lambda_{\mathrm{i}}$ ) with only a small residual impact that is firm specific. Second, only part of the productivity shock enters the error term. As noted by Shapiro (1986a), including output in a factor demand equation can completely absorb the productivity shock. When the elasticity of substitution is unity, $\zeta$ equals zero, and $u_{f_{\tau}}$ vanishes (cf. equations (4) and (6)). When $\sigma$ deviates from unity, the impact of the productivity shock is nonetheless diminished by $\zeta$ (provided returns to scale are not decreasing too sharply). Despite these arguments that OLS estimates will not be appreciably affected by $\Delta \mathrm{w}_{\mathrm{f}}$, we present two alternative estimates that are robust to simultaneity. First, we impose constant returns to scale ( $\eta=1$ implying $\beta=1$ ). Thus, $\Delta y_{f}$, the variable most likely to be correlated with $\Delta \mathrm{W}_{\mathrm{f}}$, no longer appears as a regressor. Second, we present IV estimates and Hausman tests using the variables in the $\tau=0$ interval as instruments. This procedure accounts for possible endogeneity between the error term and the $\Delta \mathrm{y}_{\mathrm{f}}$ and $\Delta \mathrm{c}_{\mathrm{f}}$ regressors.

This econometric model is robust to four potentially important distortions. First, the parameter estimates are robust to trending variables. See Appendix A for formal consideration of this issue and the role played by differencing in eliminating firm-specific trends. Second, the estimates are unlikely to be influenced by additional factors that may affect the specification of the production function or the first-order conditions. For example, the estimating equation is robust to including additional factors of production. Markups that vary across firms are captured by a firm-specific fixed effect eliminated by differencing. Moreover, the information processing revolution may have led to biased technical change over the past 20 years. In terms of the CES technology, biased technical change is represented by temporal variation in $\omega$ and, like $\mathrm{w}_{\tau}$, will be reflected in the constant. Third, studies implementing the Jorgensonian framework have often been criticized for failing to distinguish between desired output and actual output (e.g., Coen, 1969; Hall, 1995). By using time-averages in the econometric equation, we recognize this important distinction. Fourth, the estimates are unlikely to be affected by measurement error in the capital stock. Classic measurement error will be part of the error term, and hence innocuous. A plausible situation where measurement error may be systematic arises when an increase in 
the pace of technological change effectively increases the depreciation of fixed capital through obsolescence, an effect not captured in our fixed depreciation rate assumption. However, an increase in depreciation rates would lead to a systematic overstatement of capital in $\tau=2$, and would be captured by the constant. If omitted variables or measurement error are both firm-specific and interval-varying, consistent estimation becomes an issue. In this case, the IV estimates in Section IV.E, coupled with the measurement error analysis in Section IV.C, provide a useful safeguard to check the parameter estimates.

In sum, the estimation strategy developed here collapses the time dimension of firm panel data by defining three intervals and then time-averaging the data within an interval. The first interval is used to form instruments or sort variables into contrasting classes. The second and third intervals are used for estimation. Identification is provided by the cross-firm variation in capital, output, and user cost growth. A variety of productivity shocks, omitted variables, and fixed firm effects are accounted for by estimated parameters or differencing. Production function parameters are thus estimated in a cross-section of time-averaged, differenced firm data. This econometric model does not solve the estimation problems inherent with investment models - difficult-to-specify dynamics, transitory time-series variation, and positively sloped supply schedules - that may bias estimates of the elasticity. Instead, our approach avoids these problems by exploiting panel data with a method that emphasizes low-frequency variation and estimating directly the first-order condition for capital. ${ }^{10}$

\section{The Panel Dataset}

Our estimation method requires a panel dataset that is long in both the crosssection and time-series dimensions and that contains cross-sectional variation in the user cost that is key for identification. We link data sources from the Compustat Industrial Database maintained by Standard and Poors (containing financial statement data) and Data Resources, Inc. (DRI, containing user cost and industry data). In this section, we discuss the construction of the variables used for

\footnotetext{
${ }^{10}$ Of course, this approach requires the construction of an empirical measure of the capital stock which is not readily available in accounting data. This task is challenging as indicated by our capital stock measurement algorithm described in appendix B. It may also introduce measurement error, as we address in section IV.C. For this reason, among others, we view our approach as complementary to studies that estimate the user cost elasticity from investment equations with investment data that may be obtained directly from accounting statements.
} 
regression estimates of equation (7), for instruments, and for sorting firms into contrasting classes.

For the user costs (C), we have data for 26 different capital assets (24 types of equipment and two types of structures). The basis for these user costs, from Hall and Jorgenson (1967) and modified by DRI, is:

$$
\mathrm{C}_{\mathrm{i}, \mathrm{j}, \mathrm{t}}=\left[\mathrm{p}_{\mathrm{j}, \mathrm{t}}^{\mathrm{I}} / \mathrm{p}_{\mathrm{i}, \mathrm{t}}^{\mathrm{Y}}\right]\left[\left(1-\mathrm{m}_{\mathrm{j}, \mathrm{t}}-\mathrm{z}_{\mathrm{j}, \mathrm{t}}\right) /\left(1-\mathrm{tx}_{\mathrm{t}}\right)\right]\left[\mathrm{r}_{\mathrm{t}}+\delta_{\mathrm{j}}\right]
$$

where $\mathrm{p}_{j, \mathrm{t}}^{\mathrm{I}}$ is the asset-specific purchase price for asset $\mathrm{j}$ at time $\mathrm{t}, \mathrm{p}_{\mathrm{i}, \mathrm{t}}^{\mathrm{Y}}$ is the industry $i$ output price at time $t, \delta_{j}$ is the asset-specific economic depreciation rate, and $\mathrm{x}_{\mathrm{t}}$ is the income tax rate. The investment tax credit $\left(\mathrm{m}_{\mathrm{j}, \mathrm{t}}\right)$ and the discounted value of tax depreciation allowances $\left(\mathrm{z}_{\mathrm{j}, \mathrm{t}}\right)$ also vary across assets. The financial cost of capital $\left(r_{t}\right)$ is a weighted average of the cost of equity (the dividend-price ratio for Standard \& Poor's Composite Stock Price Index plus an expected longrun growth rate of 2.4 percent, with a weight of 0.67 ) and the cost of debt (average yield on new issues of high-grade corporate bonds adjusted to a AAA basis, with a weight of 0.33 ). The nominal cost of debt is reduced by its tax deductibility and the expected inflation rate, defined as a weighted average of past GDP deflator growth rates. User costs for two- and three-digit industries are a weighted average of the asset user costs. The weights are the proportion of total capital in an industry accounted for by each of the 26 assets. ${ }^{11}$ This information is then merged with the firm-level Compustat data using each firm's S.I.C. code. ${ }^{12}$

Measurement of the capital stock $(\mathrm{K})$ is important for our study. Compustat does not provide an acceptable measure of the capital stock because book values of net plant and equipment likely understate current replacement values in periods of inflation. In addition, accounting depreciation rules may not accurately reflect economic depreciation.

\footnotetext{
${ }^{11}$ These weights are from the Bureau of Economic Analysis capital flow tables and reflect asset usage by establishment. The Compustat data reflect ownership by company. The combination of industry aggregate data for the user cost and firm data for investment and other items may induce measurement error because some firms operate in a variety of industries. To the extent that such measurement error is constant within firms, however, it will be captured in firm fixed effects.

${ }^{12}$ We average the quarterly DRI user cost data at the firm level to obtain an annual user cost that corresponds to the Compustat data. The averages account for differences in firms' fiscal years, and therefore introduces some firm-level heterogeneity into the user cost data.
} 
We measure the current replacement value of capital with a three-step, iterative algorithm. ${ }^{13}$ First, choose a seed value. We use the book value of net plant and equipment from the firm's first observation in Compustat. ${ }^{14}$ The nominal seed value is deflated by a weighted average of investment goods price deflators, where the weights are determined by the specific capital asset mix of each industry. These are the same weights employed in the user cost computation described above. Second, subtract capital lost to (geometric) depreciation. The firm's depreciation rate is the weighted average of the rates for individual assets from DRI. Thus, there is a consistency between the depreciation rates used in constructing the capital stock and user cost data. Third, add in new investment. In most cases, this step simply adds the deflated value of the Compustat capital expenditures variable. The deflator is the weighted average of each industry's investment goods price deflators. At the micro level, however, we must take into account that a firm's capital stock may rise or decline due to acquisitions or divestitures that are not included in the capital expenditure variable. If the data indicate a significant acquisition or divestiture, we use accounting identities to calculate the impact of this activity on the capital stock. Details of the capital stock calculation appear in Appendix B.

Output (Y) is gross sales during the year reduced by cash discounts, trade discounts, and returned sales or allowances to customers. Sales will differ from output by the change in finished goods inventories. While this difference may be

\footnotetext{
13 This conceptual approach has been used for firm-level panel data at least since Salinger and Summers (1983).

${ }^{14}$ Because the book value of net plant will usually be less than the replacement cost when there is inflation, the use of net plant as a seed in 1972 distorts the measurement of the replacement cost of capital. This distortion, however, is unlikely to affect the estimated parameters for three reasons. First, the distortion will disappear as new investment is added to the capital stock at current replacement value and old capital is depreciated. The early part $(\tau=0)$ of our sample is used only for instruments. The effect of the seed value on the regression data, therefore, is attenuated because the capital series consist largely of new investment expenditures by the $\tau=1$ and $\tau=2$ periods. Based on the average depreciation rate of 14.8 percent, only 32.6 percent of the 1972 seed value will remain at the beginning of the estimation period in 1978. Second, a proportionate distortion of the seed value relative to the "true" replacement cost across firms is eliminated by our econometric procedure that takes logs and then first differences the capital stock data that enter the regressions. Third, any remaining random measurement error in the capital stock affects the dependent variable only and, therefore, it does not bias coefficient estimates, though it would raise standard errors.
} 
non-trivial in the short-run, it will have very little impact on the long-run averages used in our estimation. Nominal sales figures from Compustat are deflated by industry-specific output price indexes from DRI.

For some of the results that follow, we sort the data into contrasting subsamples depending on whether a classifying variable averaged over the $\tau=0$ preestimation period (1972-1977) is above or below its median. Three variables are used as classifiers: the cash flow-capital ratio $(\mathrm{CF} / \mathrm{K})$, the size of the capital stock $(\mathrm{K})$, and the Brainard-Tobin Q. Cash flow is income after taxes plus non-cash expenses, primarily depreciation and amortization. The numerator of $\mathrm{Q}$ is the market value of equity plus the book value of debt less the book value of inventories. The denominator is the replacement value of the capital stock measure discussed above.

To protect against results driven by a small number of extreme observations, we exclude observations in the one-percent upper and lower tails from the distributions of the firm-specific variables. ${ }^{15}$ Firms included in the data set must have some observations for each variable in all three of the $\tau$ intervals. Our final data set contains 1,860 firms from all sectors of the economy.

IV. Empirical Results

\section{A. Cross-Sectional Variation in Growth Rates}

The data for estimating the parameters in equation (7) consist of the growth in model variables between the $\tau=1$ and $\tau=2$ intervals that enter directly into the econometric model. While equation (7) is estimated with a cross-section of firms, the value of each firm observation is based on temporal variation between intervals. Statistics for the interval growth rates appear in the top panel of table 1. It is clear from the large coefficient of variation statistics for the growth in capital, output, and the user cost $(2.3,2.4$, and 2.7 , respectively) that there are substantial differences across firms in the regression variables. It is not surprising that capital and output growth differ across firms, but the heterogeneity in the user cost growth is remarkable relative to most other studies. We rely on this heterogeneity to

\footnotetext{
${ }^{15}$ We checked the robustness of our results when we deleted both the one-half-percent and twopercent tails. The effect on the results was negligible. Because the user cost is computed from stable industry and aggregate data, we did not delete data in the tails of the user cost variable distribution.
} 
identify $\sigma$ in this section. ${ }^{16}$

\section{B. OLS Estimates}

Ordinary least squares estimates of the structural parameters from equation (7) appear in table 2. The focus of our study is on $\sigma$. In column 1, our benchmark estimate of $\sigma$ is 0.367 with a standard error of 0.067 . The null hypothesis that the elasticity is zero can be strongly rejected at any conventional level of significance. It is also clear, however, that our estimate of $\sigma$ is much smaller than unity, the value implied by the Cobb-Douglas production function and often assumed in applied work.

As shown by equation (7), the estimated returns to scale elasticity $(\eta)$ is a function of the regression coefficients on the growth in both output $(\beta)$ and the user $\operatorname{cost}(-\sigma)$. The OLS estimate of the returns to scale elasticity, $\eta$, is 1.135 also with a small standard error. ${ }^{17}$ With our estimated parameter values, the primary reason that the estimated returns to scale elasticity modestly exceeds one is that the coefficient of output growth in our capital growth regression is somewhat less than unity $(\beta=0.925)$. As shown in equation ( 7$)$, an estimated $\beta$ in the neighborhood of unity generates results for $\eta$ close to constant returns for any admissible value of $\sigma$. It is interesting to note that the effect of output is much stronger here than in panel data studies using investment data (cf. Chirinko, Fazzari, and Meyer, 1999). We believe the reason for these more plausible results is that, unlike typical investment equations, our estimation method captures long-run, permanent changes in output, and is not affected by the transitory variation that may unduly influence investment regressions with annual or quarterly data.

\footnotetext{
16 To provide a sense of the information in the data, summary statistics for the levels of the regression variables within each interval (which do not directly enter the econometric specification) are presented in the bottom three panels of table 1. The capital and output statistics are in millions of 1987 dollars.

${ }^{17}$ The returns to scale elasticity is recovered from the estimated coefficients with the following formula: $\eta=(1-\sigma) /(\beta-\sigma)$ when $\beta>\sigma$. The variance of $\eta$ depends in a complicated way on the variances and covariances of the estimated $\sigma$ and $\beta$. We use an approximate formula based on a second-order Taylor series expansion of $\eta$ about the estimated values of $\sigma$ and $\beta$ :

$\mathrm{V}[\eta]=\left\{\mathrm{V}[\sigma](1-\beta)^{2}+\mathrm{V}[\beta](1-\sigma)^{2}-2 \mathrm{C}[\sigma, \beta](1-\beta)(1-\sigma)\right\} /(\beta-\sigma)^{4}$, where $\mathrm{V}[\cdot]$ and $\mathrm{C}[\cdot]$ are the variance and covariance operators, respectively.
} 
Table 1 - Summary Statistics

1. Percentage Change Between Interval $\tau=1$ and $\tau=2$

\begin{tabular}{|l||c||c||c|}
\hline Statistic & Capital & Output & User Cost \\
\hline Mean & 36.4 & 27.5 & -6.9 \\
\hline Median & 16.9 & 14.6 & -11.8 \\
\hline Standard Deviation & 81.9 & 66.2 & 18.7 \\
\hline Coefficient of Variation & 2.3 & 2.4 & 2.7 \\
\hline
\end{tabular}

2. Levels in Interval $\tau=0$

\begin{tabular}{|l||c||c||c|}
\hline Statistic & Capital & Output & User Cost \\
\hline Mean & 320.8 & 948.1 & 0.282 \\
\hline Median & 33.1 & 161.7 & 0.291 \\
\hline Standard Deviation & 848.7 & 2562.0 & 0.056 \\
\hline Coefficient of Variation & 2.6 & 2.7 & 0.2 \\
\hline
\end{tabular}

3. Levels in Interval $\tau=1$

\begin{tabular}{|l||c||c||c|}
\hline Statistic & Capital & Output & User Cost \\
\hline Mean & 434.2 & 1169.5 & 0.242 \\
\hline Median & 50.7 & 211.9 & 0.246 \\
\hline Standard Deviation & 1141.3 & 3180.5 & 0.046 \\
\hline Coefficient of Variation & 2.6 & 2.7 & 0.2 \\
\hline
\end{tabular}

\section{Levels in Interval $\tau=2$}

\begin{tabular}{|l||c||c||c|}
\hline Statistic & Capital & Output & User Cost \\
\hline Mean & 529.2 & 1404.2 & 0.219 \\
\hline Median & 62.3 & 253.7 & 0.218 \\
\hline Standard Deviation & 1410.1 & 4237.4 & 0.028 \\
\hline Coefficient of Variation & 2.7 & 3.0 & 0.1 \\
\hline
\end{tabular}

Note: The statistics are derived from a sample of 1,860 firms constructed from Compustat and DRI sources as described in section III of the text. The standard deviations represent cross-sectional differences arising from firm heterogeneity in percentage changes across the $\tau=1$ and $\tau=2$ intervals (panel 1) and from firm heterogeneity in levels within an interval (panels 2, 3, and 4). Level statistics for capital and output are in millions of 1987 dollars. 


\section{Table 2 - Ordinary Least Squares Estimates}

\begin{tabular}{|c|c|c|c|c|c|}
\hline & \multicolumn{2}{|c|}{ Unconstrained Regressions } & \multicolumn{2}{|c|}{ Constrained Regressions } & \multirow{2}{*}{\begin{tabular}{|c} 
Unconstrained \\
Regression \\
with Low-Pass \\
Filter \\
\end{tabular}} \\
\hline & $\begin{array}{l}\text { Benchmark } \\
\text { Model }\end{array}$ & $\begin{array}{c}\text { Model with } \\
\text { Two-Digit SIC } \\
\text { Dummies } \\
\end{array}$ & $\eta=1$ & $\begin{array}{c}\sigma=1 \text { and } \\
\eta=1\end{array}$ & \\
\hline$\sigma$ & $\begin{array}{c}0.367 \\
(0.067)\end{array}$ & $\begin{array}{c}0.440 \\
(0.293)\end{array}$ & $\begin{array}{c}0.372 \\
(0.067)\end{array}$ & 1.0 & $\begin{array}{c}0.352 \\
(0.057)\end{array}$ \\
\hline$\eta$ & $\begin{array}{l}1.135 \\
(0.042)\end{array}$ & $\begin{array}{l}1.152 \\
(0.102)\end{array}$ & 1.0 & 1.0 & $\begin{array}{l}1.368 \\
(0.070)\end{array}$ \\
\hline$\beta$ & $\begin{array}{c}0.925 \\
(0.019)\end{array}$ & $\begin{array}{c}0.926 \\
(0.019)\end{array}$ & 1.0 & 1.0 & $\begin{array}{c}0.825 \\
(0.019)\end{array}$ \\
\hline$\gamma$ & $\begin{array}{c}0.084 \\
(0.014)\end{array}$ & $\begin{array}{l}-0.055 \\
(0.114)\end{array}$ & $\begin{array}{c}0.063 \\
(0.013)\end{array}$ & $\begin{array}{c}0.020 \\
(0.013)\end{array}$ & $\begin{array}{c}0.100 \\
(0.016)\end{array}$ \\
\hline $\mathbf{R}^{2}$ & 0.564 & 0.593 & 0.560 & 0.540 & 0.494 \\
\hline
\end{tabular}

Note: Estimates of equation (7) with firm-level panel data as described in sections II and III. Standard errors appear in parentheses. The parameters are $\sigma$ (the capital-labor substitution or user cost elasticity), $\eta$ (the returns to scale elasticity), $\beta$ (the regression coefficient on output growth) and $\gamma$ (the intercept). See section IV.B for the formula used to compute $\eta$ and its standard error.

The second column of table 2 presents results from including two-digit industry dummies in the benchmark regression (the $\lambda_{i}$ terms in equation 7 ). These dummies control for industry-level productivity shocks between intervals $\tau=1$ and $\tau=2$ or, more generally, any industry-specific effects. The structural parameter estimates do not change much when the dummies are included. The $\sigma$ estimate rises from 0.367 to 0.440 , and $\eta$ is virtually identical. The standard error of $\sigma$, however, rises by a factor of more than four. The $\sigma$ estimate is therefore much less precise with industry dummies in the model. For this reason and given the modest change in $\sigma$, the remaining regressions in table 2 exclude the industry dummies.

As discussed in Section II, the most likely source of correlation between the 
error term and the independent variables in these OLS regressions comes from the correlation between firm-specific productivity shocks embedded in the error term and firm output growth. This potential simultaneity problem can be avoided by imposing constant returns to scale $(\eta=1$ implying $\beta=1$ ), an assumption that removes output growth as a regressor. The third column of table 2 presents a regression with the output growth coefficient constrained to unity. The $\sigma$ estimate changes only trivially when constant returns to scale are imposed (from 0.367 to $0.372){ }^{18}$ These result supports our contention that $\sigma$ is consistently estimated by OLS in our framework.

The final column of table 2 presents estimates based on the assumption of a Cobb-Douglas production function, which is defined by a unitary elasticity of substitution $(\sigma=1)$ and constant returns to scale $(\eta=1)$. Not surprisingly given the prior results for $\sigma$ and $\eta$, the restrictions associated with the Cobb-Douglas are easily rejected at the one-percent level relative to the unconstrained model in the first column.

\section{Measurement Error}

What role might measurement error play in biasing the estimated $\sigma$ downward and away from a unitary elasticity (as emphasized recently for investment models by Goolsbee, 2000)? We consider three sources of measurement error.

First, measurement error introduced in the construction of the capital stock will have a modest effect on the estimates because the capital stock enters as the dependent variable. In situations where measurement error in the dependent variable takes the classic form or is fixed for a given firm, industry, or interval, the elasticity estimates will be unaffected.

Second, measurement error in the independent variables may arise for various reasons and can have direct and indirect effects on the estimated $\sigma$. To assess the direct effects, assume that the true value of this elasticity is unity. If the OLS estimate is inconsistent because $\Delta \mathrm{c}_{\mathrm{f}}$ is afflicted with classic measurement error, the variance of this measurement error would have to account for at least 60

\footnotetext{
${ }^{18}$ While the $\mathrm{R}^{2}$ decreases trivially from 0.564 (column 1 ) to 0.560 (column 3 ), the constraint of constant returns to scale is rejected at the one-percent level, a result driven by the large number of observations used in estimation.
} 
percent of the variance in the observed $\Delta \mathrm{c}_{\mathrm{f} .}{ }^{19}$ This seems highly implausible, especially since the estimator accounts for measurement error arising from fixed firm, industry, and interval effects by differencing. An indirect effect could result from measurement error in the other independent variable. If $\Delta \mathrm{y}_{\mathrm{f}}$ is measured with error, we can use the formula proposed by Rao (1973) and an auxiliary regression of $\Delta y_{f}$ on $\Delta c_{f}$ to assess the extent of bias on $\sigma$. Making the rather extreme assumption that one-half of the variance of $\Delta \mathrm{y}_{\mathrm{f}}$ is measurement error, we obtain the somewhat surprising result that the estimated $\sigma$ is biased upward toward unity. However, the bias is a trivial $0.043 .^{20}$

Third, the assumption that the long-run values of $\mathrm{K}$ and $\mathrm{Y}$ appearing in the model of Section II are measured as time-averages over a $\tau$ interval may not be valid because of various short-run frictions. For example, irreversibility constraints or asymmetric adjustment costs suggest the possibility that the average values of $\mathrm{K}$ and $\mathrm{Y}$ might differ from their long-run values in a frictionless model. As shown in Appendix $\mathrm{C}$, these short-run frictions introduce measurement error into $\mathrm{K}$ and $\mathrm{Y}$. The effects of measurement error on $\sigma$ have been analyzed above. Measurement error can adversely affect the reported results but, with our estimation strategy, it does not appear to be quantitatively important.

\section{An Alternative Interpretation}

The interval-difference estimator that generated the results in Table 2 consists of two steps: 1) average the data over non-overlapping intervals of years and 2) first difference the log of the averaged data across intervals. The first part of our estimation strategy can be interpreted in terms of a low-pass filter (LPF) defined in the frequency domain. ${ }^{21}$ A LPF allows frequencies lower than some

${ }^{19}$ The asymptotic bias on the estimated $\sigma$ is given by the following formula: $\left(\sigma^{\#}-\sigma^{\prime}\right)=$ $\left(\operatorname{VAR}\left[\xi_{\mathrm{f}}\right] / \operatorname{VAR}\left[\Delta \mathrm{c}_{\mathrm{f}}\right]\right) \sigma^{\#}$, where $\sigma^{\prime}$ and $\sigma^{\#}$ are the estimated and true values of $\sigma$, respectively, and $\xi_{\mathrm{f}}$ is the measurement error. If $\sigma^{\#}=1$, then the variance ratio must be at least equal to 0.60 given an OLS estimate of $\sigma^{\prime}=0.40$.

${ }^{20}$ The bias on the estimated $\sigma$ is $\left(\sigma^{\#}-\sigma^{\prime}\right)=-\left(\left(\beta b_{\Delta y, \Delta c}\right) /\left(1-R_{\Delta y, \Delta c}^{2}\right)\right)\left(\operatorname{VAR}\left[\xi_{f}\right] / \operatorname{VAR}\left[\Delta y_{f}\right]\right)$, where $\sigma^{\prime}$ and $\sigma^{\#}$ are the estimated and true values of $\sigma$, respectively, $\beta$ is from equation (7), $\mathrm{b}_{\Delta \mathrm{y}, \Delta \mathrm{c}}$ is the coefficient on $\Delta \mathrm{c}_{\mathrm{f}}, \mathrm{R}_{\Delta \mathrm{y}, \Delta \mathrm{c}}$ the correlation coefficient from the auxiliary regression of $\Delta \mathrm{y}_{\mathrm{f}}$ on $\Delta \mathrm{c}_{\mathrm{f}}$ and a constant, and $\xi_{\mathrm{f}}$ is the measurement error. We assume that one-half of the variance in the output variable is measurement error; hence, $\operatorname{VAR}\left[\xi_{\mathrm{f}}\right] / \operatorname{VAR}\left[\Delta \mathrm{y}_{\mathrm{f}}\right]=0.50$. We further assume that $\beta$ equals its estimated value under IV of 1.402. From the auxiliary regression, $b_{\Delta y, \Delta c}=0.061$ and $R_{\Delta y, \Delta c}^{2}=0.0003$; hence, $\left(\sigma^{\#}-\sigma^{\prime}\right)=-0.043$.

${ }^{21}$ We thank Julio Rotemberg for suggesting this interpretation of our estimator. 
critical frequency, $\omega^{\#}$, to pass through to the transformed series, but excludes frequencies higher than $\omega$. Baxter and King (1999, Section II.B) present the formulas that translate restrictions from the frequency domain into the time domain. For an input series $\mathrm{x}(\mathrm{t})$ and an interval of seven years, the LPF for a critical value $\omega^{\#}\left(\operatorname{LPF}\left[\omega^{\#}\right]\right)$ produces the following transformed series $\left(x^{\#}(t)\right)$,

$$
\begin{aligned}
& \mathrm{x}^{\#}(\mathrm{t})=\sum_{\mathrm{h}=-3}^{3} \mathrm{a}(\mathrm{h}) \mathrm{L}(\mathrm{h}) \mathrm{x}(\mathrm{t}), \\
& \mathrm{a}(0)=\omega^{\#} / \pi+\theta, \\
& \mathrm{a}(\mathrm{h})=\sin \left(|\mathrm{h}| * \omega^{\#}\right) /(|\mathrm{h}| * \pi)+\theta, \\
& \theta=\left(1-\sum_{\mathrm{h}=-3}^{3} \mathrm{a}(\mathrm{h})\right) / 7,
\end{aligned}
$$

where $\mathrm{L}(\mathrm{h})$ is a polynomial in the lag operator and $\theta$ normalizes the variance to be unity at the $0^{\text {th }}$ frequency.

The estimator used for the results presented thus far can be interpreted as a limiting case of LPF $\left[\omega^{\#}\right]$. With $\omega^{\#}$ at its lower bound of zero, all of the a(h) coefficients are initially zero by (9b) and (9c). The value of $\theta$ becomes $1 / 7$, and equal weight is given to each observation in the interval. Stationarity is not an issue because the second step of the interval-difference estimator involves a firstdifference. The use of the lower bound for $\omega$ " is consistent with our objective to emphasize long-run variation.

As a robustness check on our empirical results, we experiment with an alternative assumption about the frequencies allowed to pass through to the transformed data. We assume that frequencies with periods greater than or equal to seven years define the long-run. Based on the relation between period and frequency, this implies $\omega^{\#}=0.8976$. We replace equal weights of 0.1429 (one seventh) in our basic estimator with the weights implied by (9b) and (9c) for $\omega^{\#}=$ 0.8976: $\mathrm{a}(\mathrm{h}=-3)=\mathrm{a}(\mathrm{h}=3)=0.0194, \mathrm{a}(\mathrm{h}=-2)=\mathrm{a}(\mathrm{h}=2)=0.1286, \mathrm{a}(\mathrm{h}=-1)=\mathrm{a}(\mathrm{h}=1)$ $=0.2223$, and $\mathrm{a}(\mathrm{h}=0)=0.2594$. The results are presented in the fifth column of Table 2, and the estimate of $\sigma$ is 0.352 (with a standard error of 0.057 ), which is 
very close to the estimate obtained when the long-run was defined in terms of $\omega^{\#}=$ 0 . Thus, estimates of $\sigma$ are robust to definitions of the long-run, and subsequent results are based on our assumption that $\omega^{\#}=0$.

\section{E. IV Estimates}

The OLS estimates of equation (7) are consistent under the assumption that the error term is independent of both output and user cost growth. As discussed in Section II and suggested by the results with the constant returns model in Section IV.B, these are reasonable assumptions with our estimation method. Nonetheless, we present instrumental variables estimates in table 3 to explore the robustness of our OLS results. The instruments are constructed from data in the $\tau=0$ interval. The instrument list includes the user cost $\left(\mathrm{C}_{\mathrm{i}, \tau=0}\right)$, capital stock $\left(\mathrm{K}_{\mathrm{i}, \tau=0}\right)$, the outputcapital ratio $\left((\mathrm{Y} / \mathrm{K})_{\mathrm{i}, \tau=0}\right)$, and the cash flow-capital ratio $\left((\mathrm{CF} / \mathrm{K})_{\mathrm{i}, \tau=0}\right)$. In addition, we included the annualized growth rates of capital, output, cash flow, accounts receivable, and cash and cash equivalents defined over the $\tau=0$ interval.

The benchmark IV estimate of $\sigma$ in the first column of table 3, 0.390 is almost identical to the benchmark OLS estimate from table 2 of 0.367 . Not surprisingly, the standard error rises with IV, but we can still strongly reject both the hypotheses that $\sigma$ equals zero or unity. Unfortunately, the IV estimates of $\eta$ are not as reasonable. Because of the large coefficient on output growth $(\beta)$, the point estimate of the returns to scale elasticity $(\eta)$ is 0.603 . The standard error of $\eta$ is much larger with IV than with OLS, but the IV estimate still rejects constant returns to scale in favor of decreasing returns. However, we do not consider this result reliable because of our inability to find good instruments for output growth.

The partial $\mathrm{R}^{2}$ statistic developed by Shea (1997) provides quantitative confirmation of this interpretation. This statistic measures the relevance of instruments for each estimated coefficient after removing the explanatory power used in instrumenting other regressors. The partial $R^{2}$ for $\beta$ is 0.040 , dramatically lower than the partial $\mathrm{R}^{2}$ of 0.515 for $\sigma .^{22}$

22 The partial $\mathrm{R}^{2}$ statistic is preferable to the more common first-stage $\mathrm{R}^{2}$ as discussed by Shea (1997). 


\section{Table 3 - Instrumental Variables Estimates}

\begin{tabular}{|c|c|c|c|c|}
\hline & \multicolumn{2}{|c|}{ Unconstrained Regressions } & \multicolumn{2}{|c|}{ Constrained Regressions } \\
\hline & $\begin{array}{c}\text { Benchmark } \\
\text { Model }\end{array}$ & $\begin{array}{c}\text { Model with Two- } \\
\text { Digit SIC Dummies }\end{array}$ & $\eta=1$ & $\sigma=1$ and $\eta=1$ \\
\hline$\sigma$ & $\begin{array}{c}0.390 \\
(0.108)\end{array}$ & $\begin{array}{c}0.373 \\
(0.286)\end{array}$ & $\begin{array}{c}0.434 \\
(0.093)\end{array}$ & 1.0 \\
\hline$\eta$ & $\begin{array}{c}0.603 \\
(0.074)\end{array}$ & $\begin{array}{c}0.633 \\
(0.120)\end{array}$ & 1.0 & 1.0 \\
\hline$\beta$ & $\begin{array}{c}1.402 \\
(0.110)\end{array}$ & $\begin{array}{c}1.364 \\
(0.118)\end{array}$ & 1.0 & 1.0 \\
\hline$\gamma$ & $\begin{array}{l}-0.049 \\
(0.034)\end{array}$ & $\begin{array}{l}-0.324 \\
(0.134)\end{array}$ & $\begin{array}{c}0.059 \\
(0.014)\end{array}$ & $\begin{array}{c}0.020 \\
(0.013)\end{array}$ \\
\hline
\end{tabular}

Note: Estimates of equation (7) with firm-level panel data as described in section III. Standard errors appear in parentheses. The parameters are $\sigma$ (the capital-labor substitution or user cost elasticity), $\eta$ (the returns to scale elasticity), $\beta$ (the regression coefficient on output growth), and $\gamma$ (the intercept). The instrument list is defined in section IV.C. In the second column, the industry dummies are instrumented by themselves. See section IV.B for the formula used to compute $\eta$ and its standard error.

To pursue this issue one step further, we re-estimate the model with IV imposing constant returns to scale $(\eta=1)$. Under this assumption, $\beta=1$, and we no longer need to instrument output growth. The results appear in the third column of table 2. The IV estimate of $\sigma$ is only modestly affected by imposing constant returns. The elasticity estimate rises to 0.434 from 0.390 , a change much smaller than one standard error. This result demonstrates that, even if the IV estimate of returns to scale is unreliable due to the lack of relevant instruments for output growth, this difficulty does not "contaminate" conclusions about $\sigma$, which is the primary focus of our study.

The second column of table 3 presents IV estimates with two-digit industry dummies. This specification accounts for industry-level productivity shocks 
between the $\tau=1$ and $\tau=2$ periods (cf. equation (7)). The point estimate of $\sigma$ hardly changes from the benchmark value $(0.373$ versus 0.390$)$. As was the case for the OLS estimates with industry dummies, however, the standard error of $\sigma$ rises dramatically, almost by a factor of three. ${ }^{23}$

As a final test of the validity of the OLS estimates, we performed Hausman tests on the $\sigma$ parameters. The Hausman statistics are asymptotically distributed $\chi^{2}(1)$ under the null hypothesis that the OLS estimates are consistent. For the benchmark model, the test statistic is 0.07 and for the constant returns to scale model it is $0.92 .{ }^{24}$ Both test statistics are far below the 90 percent critical value for the $\chi^{2}(1)$ distribution of 2.71. These tests support the validity of the OLS estimates of $\sigma$. Taken together, the unconstrained OLS and IV estimates strongly suggest that $\sigma$ is approximately 0.40 .

\section{F. Split-Sample Estimates}

Table 4 explores our results further by assessing the stability of structural parameter estimates in several sub-samples chosen to address issues that have arisen with empirical investment models. In each sub-sample, we expect $\sigma$ to remain similar to its value in the full sample results. All estimates are with the benchmark model. The first panel presents results with the sample split by the ratio of cash flow to the capital stock. In investment regressions using annual data, Chirinko, Fazzari, and Meyer (1999) found that including cash flow had a significant effect on the estimated $\sigma$. We interpreted that finding in the context of the extensive literature on finance constraints and firms' investment spending. The approach here, however, emphasizes the long-run impact of the user cost on the capital stock. We therefore expect financial constraints to be less important. The first panel of table 3 presents results from data split according to the pre-sample median cash flow-capital ratio. If financial constraints were important at the horizon relevant for our estimation, we would expect the estimated $\sigma$ to be significantly different across high and low cash flow firms that differ by their inadequate access to finance. There is little evidence of such an effect in our data. The OLS point estimate of $\sigma$ is somewhat larger for the high cash flow firms than

\footnotetext{
${ }^{23}$ Because of collinearity, it was not useful to include industry dummies in the model as both regressors and instruments. In the second column of table 2, the instrument set for output and user cost growth is the same as for the other IV regressions; the industry dummies are instrumented by themselves.

${ }^{24}$ The Hausman test is not defined for the model that includes industry dummies because the standard error of the IV estimate is slightly smaller than the standard error of the OLS estimate.
} 
for low cash flow firms, but the difference is less than two standard errors. Similar results hold for the IV regressions except that $\sigma$ is relatively larger for the low cash flow firms. The formal test statistics ( $\theta$ 's) for the equality of the $\sigma$ 's from the two sub-samples have $\mathrm{p}$-values greater than 0.35 , easily sustaining the null hypothesis of equal $\sigma$ 's. ${ }^{25}$

Our second sort is by size, defined by the median average capital stock in the pre-sample period $(\tau=0)$. The technologies utilized by firms may vary systematically by size, and the technology parameters estimated here may change accordingly. Moreover, size is frequently used to identify firms that may be finance constrained. External finance may be relatively costly for smaller firms because they are not able to bear the substantial fixed costs of obtaining external funding or they lack visibility in external capital markets. Relative to the results in table 2, the OLS point estimates of $\sigma$ are higher for small firms and lower for large firms. With IV, the point estimates have the reverse pattern, and both are lower than the comparable estimate of 0.390 based on the full sample (table 3 ). None of these differences is statistically significant.

Finally, we split the data at the median value of the Brainard-Tobin Q variable to address how sensitive our estimation strategy is to investment dynamics and shocks. Firms with high values of Q are presumably further from their long-run equilibrium capital stock for, among other reasons, favorable demand or productivity shocks. Therefore, if our estimation method did not adequately account for investment dynamics or shocks, we might expect a difference in the estimated $\sigma$ 's across the high-Q and low-Q sub-samples. In table 4, the elasticities are virtually identical in the OLS results across the $\mathrm{Q}$ sub-samples. The low- $\mathrm{Q}$ firms have a modestly higher elasticity than the high-Q firms in the IV regression, but the difference is not statistically significant. This result provides additional support for the way our estimation method addresses problems with complicated investment dynamics, avoiding these difficult specification issues by focusing directly on the long-run growth of the capital stock.

25 The null hypothesis that $\sigma^{\prime}=\sigma$ " (where the ' and " refer to estimates based on the low and high sub-samples, respectively) is evaluated by $\theta$ in the following auxiliary equation based on equation (7): $\Delta \mathrm{k}_{\mathrm{f}}=-\sigma \Delta \mathrm{c}_{\mathrm{f}}-\theta \Delta \mathrm{c}_{\mathrm{f}} * \mathrm{I}_{\mathrm{f}}+\beta^{\prime} \Delta \mathrm{y}_{\mathrm{f}} * \mathrm{I}_{\mathrm{f}}+\beta^{\prime \prime} \Delta \mathrm{y}_{\mathrm{f}} *\left(1-\mathrm{I}_{\mathrm{f}}\right)-\gamma^{\prime} * \mathrm{I}_{\mathrm{f}}-\gamma^{\prime \prime} *\left(1-\mathrm{I}_{\mathrm{f}}\right)-$ $\Delta \mathrm{w}_{\mathrm{f}}$, where $\mathrm{I}_{\mathrm{f}}$ is an indicator variable equal to 1 for the low sub-sample and 0 for the high subsample and $\theta=\sigma^{\prime}-\sigma^{\prime \prime}$ and is distributed asymptotic $t$ under the null hypothesis that $\sigma$ ' $=\sigma$ ". In the IV regressions, each individual instrument, $\mathrm{z}_{\mathrm{f}}$, appears twice in the instrument list as follows, $\mathrm{Z}_{\mathrm{f}} * \mathrm{I}_{\mathrm{f}}$ and $\mathrm{z}_{\mathrm{f}} *\left(1-\mathrm{I}_{\mathrm{f}}\right)$. 


\section{Table 4 - Ordinary Least Squares And Instrumental Variable Estimates: Various Sample Splits}

\begin{tabular}{|c|c|c|c|c|c|c|c|c|c|c|c|c|}
\hline & \multicolumn{4}{|c|}{ Split by Cash Flow-Capital Ratio } & \multicolumn{4}{|c|}{ Split by Capital Stock Size } & \multicolumn{4}{|c|}{ Split by Tobin-Brainard Q } \\
\hline & \multicolumn{2}{|c|}{ OLS } & \multicolumn{2}{|c|}{ IV } & \multicolumn{2}{|c|}{ OLS } & \multicolumn{2}{|c|}{ IV } & \multicolumn{2}{|c|}{ OLS } & \multicolumn{2}{|c|}{ IV } \\
\hline & $\begin{array}{l}\text { Low } \\
\mathrm{CF} / \mathrm{K} \\
\end{array}$ & $\begin{array}{l}\text { High } \\
\mathrm{CF} / \mathrm{K} \\
\end{array}$ & $\begin{array}{c}\text { Low } \\
\mathrm{CF} / \mathrm{K} 1 \\
\end{array}$ & $\begin{array}{l}\text { High } \\
\mathrm{CF} / \mathrm{K}\end{array}$ & $\begin{array}{c}\text { Low } \\
\text { Capital } \\
\end{array}$ & $\begin{array}{c}\text { High } \\
\text { Capital }\end{array}$ & $\begin{array}{c}\text { Low } \\
\text { Capital } \\
\end{array}$ & $\begin{array}{c}\text { High } \\
\text { Capital }\end{array}$ & $\begin{array}{c}\text { Low } \\
\text { Q }\end{array}$ & $\begin{array}{c}\text { High } \\
\mathrm{Q}\end{array}$ & $\begin{array}{c}\text { Low } \\
\text { Q }\end{array}$ & $\begin{array}{c}\text { High } \\
\mathrm{Q}\end{array}$ \\
\hline$\sigma$ & $\begin{array}{c}0.278 \\
(0.075)\end{array}$ & $\begin{array}{c}0.407 \\
(0.127)\end{array}$ & $\begin{array}{c}0.364 \\
(0.102)\end{array}$ & $\begin{array}{c}0.317 \\
(0.198)\end{array}$ & $\begin{array}{c}0.435 \\
(0.139)\end{array}$ & $\begin{array}{c}0.294 \\
(0.066)\end{array}$ & $\begin{array}{c}0.226 \\
(0.226)\end{array}$ & $\begin{array}{c}0.363 \\
(0.094)\end{array}$ & $\begin{array}{c}0.320 \\
(0.076)\end{array}$ & $\begin{array}{c}0.349 \\
(0.114)\end{array}$ & $\begin{array}{c}0.448 \\
(0.110)\end{array}$ & $\begin{array}{c}0.290 \\
(0.163)\end{array}$ \\
\hline$\eta$ & $\begin{array}{c}1.308 \\
(0.071)\end{array}$ & $\begin{array}{c}1.019 \\
(0.049)\end{array}$ & $\begin{array}{c}0.989 \\
(0.197)\end{array}$ & $\begin{array}{c}0.673 \\
(0.128)\end{array}$ & $\begin{array}{c}1.042 \\
(0.056)\end{array}$ & $\begin{array}{c}1.284 \\
(0.064)\end{array}$ & $\begin{array}{c}0.646 \\
(0.104)\end{array}$ & $\begin{array}{c}0.782 \\
(0.120)\end{array}$ & $\begin{array}{c}1.214 \\
(0.061)\end{array}$ & $\begin{array}{c}1.046 \\
(0.054)\end{array}$ & $\begin{array}{c}0.736 \\
(0.169)\end{array}$ & $\begin{array}{c}0.688 \\
(0.162)\end{array}$ \\
\hline$\beta$ & $\begin{array}{c}0.830 \\
(0.025)\end{array}$ & $\begin{array}{c}0.989 \\
(0.028)\end{array}$ & $\begin{array}{c}1.007 \\
(0.128)\end{array}$ & $\begin{array}{c}1.331 \\
(0.178)\end{array}$ & $\begin{array}{c}0.977 \\
(0.029)\end{array}$ & $\begin{array}{c}0.844 \\
(0.024)\end{array}$ & $\begin{array}{c}1.424 \\
(0.172)\end{array}$ & $\begin{array}{c}1.177 \\
(0.120)\end{array}$ & $\begin{array}{c}0.880 \\
(0.025)\end{array}$ & $\begin{array}{c}0.972 \\
(0.032)\end{array}$ & $\begin{array}{c}1.198 \\
(0.168)\end{array}$ & $\begin{array}{c}1.322 \\
(0.234)\end{array}$ \\
\hline$\gamma$ & $\begin{array}{c}0.040 \\
(0.017)\end{array}$ & $\begin{array}{c}0.125 \\
(0.024)\end{array}$ & $\begin{array}{c}0.000 \\
(0.031)\end{array}$ & $\begin{array}{c}0.014 \\
(0.066)\end{array}$ & $\begin{array}{c}0.105 \\
(0.026)\end{array}$ & $\begin{array}{c}0.064 \\
(0.016)\end{array}$ & $\begin{array}{l}-0.016 \\
(0.058)\end{array}$ & $\begin{array}{l}-0.019 \\
(0.033)\end{array}$ & $\begin{array}{c}0.057 \\
(0.016)\end{array}$ & $\begin{array}{c}0.107 \\
(0.027)\end{array}$ & $\begin{array}{l}-0.006 \\
(0.034)\end{array}$ & $\begin{array}{l}-0.018 \\
(0.090)\end{array}$ \\
\hline$\theta$ & \multicolumn{2}{|c|}{$\begin{array}{l}-0.129 \\
(0.144)\end{array}$} & \multicolumn{2}{|c|}{$\begin{array}{c}0.047 \\
(0.214)\end{array}$} & \multicolumn{2}{|c|}{$\begin{array}{c}0.141 \\
(0.144)\end{array}$} & \multicolumn{2}{|c|}{$\begin{array}{c}-0.137 \\
(0.226)\end{array}$} & \multicolumn{2}{|c|}{$\begin{array}{c}-0.029 \\
(0.137)\end{array}$} & \multicolumn{2}{|c|}{$\begin{array}{c}0.158 \\
(0.197)\end{array}$} \\
\hline $\mathbf{R}^{2}$ & 0.541 & 0.575 & & & 0.556 & 0.582 & & & 0.631 & 0.562 & & \\
\hline
\end{tabular}

Note: Estimates of equation (7) with firm-level panel data as described in sections II and III. Standard errors appear in parentheses. The parameters are $\sigma$ (the capital-labor substitution or user cost elasticity), $\eta$ (the returns to scale elasticity), $\beta$ (the regression coefficient on output growth), and $\gamma$ (the intercept). The instrument list is defined in section IV.E. See section IV.B for the formula used to compute $\eta$ and its standard error. Sample splits are based on the median value of the classifying variable in the $\tau=0(1972-1977)$ interval. $\theta$ is the coefficient measuring the difference between the $\sigma$ 's for the contrasting classes, and is distributed asymptotic $t$ under the null hypothesis of equality. See section IV.F for further details about this statistic. 


\section{G. Comparison to Other Approaches}

Prior studies estimating $\sigma$ (the substitution or user cost elasticity) can be set into three categories. Most previous research has been based on time-series data at the aggregate or industry levels. Prominent examples of this work are the exchanges between Hall and Jorgenson $(1967,1969,1971)$ and Eisner and Nadiri $(1968,1970)$, Eisner $(1969,1970)$, and Coen (1969). Hall and Jorgenson's initial work was based on a Cobb-Douglas production function, and hence $\sigma$ equals 1.00 by assumption. Eisner and Nadiri estimated $\sigma$ freely, and reported that the responsiveness of capital to its user cost was 0.16 . This gap has not been closed by subsequent research. Several important concerns, however, have been raised about elasticities estimated from aggregate data suggesting that such estimates may be biased downward due to problems with firm heterogeneity, simultaneity, measurement error, and capital market frictions.

These issues were difficult to address with aggregate data because of the limited amount of variation, and a more recent set of studies has exploited the substantial information in panel data. While some of these concerns can be addressed, these studies usually remove firm effects by differencing; thus, transitory time-series variation heavily influences the estimated elasticity. A recent example is Chirinko, Fazzari, and Meyer (1999), who find an elasticity of 0.25 for a panel of firms. A similar elasticity is reported by Goolsbee (2000), who analyzes a panel of equipment assets. Cummins and Hassett (1992) and Cummins, Hassett, and Hubbard $(1994,1996)$ develop a novel approach, focusing on those years in which there are sizeable tax policy changes to mitigate concerns about endogeneity and measurement error. In these studies, cross-section variation is key and they report a substantial response of investment to the user cost. Nonetheless, based on some auxiliary assumptions, the implied capital elasticity for U.S. firm data in Cummins, Hassett, and Hubbard (1994) is somewhat lower than that obtained by Chirinko, Fazzari, and Meyer. ${ }^{26}$ These studies use investment data, and the biases associated with investment models mentioned above may be important.

A third class of studies focuses on long-run relations between the capital stock and its determinants. To mitigate the distorting effects of complex dynamics, Caballero (1994) exploits the innovative idea that the elasticity can be estimated in a cointegrating equation that includes the capital/output ratio and the user cost. Because cointegration is an asymptotic property, this estimate can be biased downward in finite samples. Using aggregate quarterly data for equipment

\footnotetext{
${ }^{26}$ See Chirinko, Fazzari, and Meyer (1999, section 5) for further details.
} 
spending and the Stock-Watson (1993) correction to adjust the estimates for the effects of transitory variation, Caballero obtains a range of elasticity estimates, from 0.40 to 0.93 , depending on the number of lags used in the correction. Also exploiting cointegration properties, Mairesse, Hall, and Mulkay (1999) and Harhoff and Ramb (2001) estimate error correction models (ECM) containing the long-run relation between the capital stock and its determinants and the percentage changes in these variables to capture short-run dynamics. Firm-level data and fixed effects are used in both studies. The parameters are imprecisely estimated, a result that may be due to estimating both long-run and short-run parameters in the ECM with data that have substantial transitory time-series variation. Kiyotaki and West (1996) specify a model that includes deviations of the desired from the actual capital stock, and estimate desired capital in terms of a future projection from a two-step VAR procedure. With quarterly aggregate data for Japan, they find that the short-run and long-run user cost elasticities are 0.05 and 0.07 , respectively. The authors attribute these very small responses to transitory variation in the user cost series as represented by a pronounced tendency for mean reversion. Caballero, Engel, and Haltiwanger (1995) estimate a model similar to Caballero (1994) with plant-level equipment spending. They obtain a range of elasticities across two-digit industries from 0.01 to 2.00 , with an unweighted average of approximately unity. If we assume that the structures elasticity is one-third as large as that for equipment (per the results of Cummins and Hassett, 1992), then the overall elasticity is approximately 0.70 .

The elasticity estimates of Caballero, Engel, and Haltiwanger and those presented in this paper are both based on a panel, but are not directly comparable for a variety of reasons, including the use of plant-level vs. firm-level data, the specification of the long-run determinants of the capital stock, and the manner in which the problem of capital stock dynamics is addressed. The Caballero, Engel, and Haltiwanger estimates are based on a cointegrating relation that emphasizes the time dimension of the panel, and deviations from long-run values are accounted for with the Stock-Watson correction. By contrast, our approach uses the time dimension of panel data to measure long-run variables in each interval, and then estimates the elasticity from the cross-section dimension of the panel. Given these differences, it is not surprising that we obtain different results. 


\section{Summary and Conclusions}

The substitution elasticity between capital and labor (equivalent to the elasticity of business capital to its user cost) has been the focus of much research attention over the past 40 years. Among other issues, this parameter is central in assessing the validity of alternative models of long-run growth and translating the effects of tax policy into real outcomes. Prior work has relied in almost all cases on time-series variation in investment data at the aggregate, industry, or firm level to estimate this elasticity. This paper offers a different approach. The estimation strategy developed here classifies the time periods into three intervals and then averages the firm-level panel data within each interval. The data are differenced across intervals, and production function parameters are estimated in a crosssection of time-averaged, differenced firm data. Our approach accounts for a variety of productivity shocks, omitted variables, and firm effects. This econometric model does not solve the estimation problems inherent with investment models -- difficult-to-specify dynamics, transitory time-series variation, and positively sloped supply schedules -- that may bias estimates of the substitution/user cost elasticity. Instead, our approach avoids these problems by exploiting panel data in an original way and estimating directly the first-order condition for capital.

We find that the elasticity can be consistently and precisely estimated by OLS, and is approximately 0.40 . Relative to a comparable investment study (Chirinko, Fazzari, and Meyer, 1999), the results here suggest that investment models impart a discernible bias toward zero in estimates of the elasticity. To the central question of whether the Cobb-Douglas assumption is valid, our results offer a strikingly negative answer. This robust finding raises questions about the frequent use of the Cobb-Douglas production function in theoretical and empirical models and about the cost-effectiveness of various tax proposals for stimulating capital formation.

Apart from our immediate objective, the method developed here may prove useful in estimating other structural parameters from long-panel datasets. Our approach, which uses interval averages to estimate long-run desired values of regression variables, could be applied to other problems where short-run dynamics may obscure long-run structural relations. There are likely to be a number of applications in, for example, labor and industrial organization, where the availability of long-panels and interest in structural parameters may make this method feasible and informative. 


\section{References}

Abel, Andrew B., and, Eberly, Janice E., “The Effects Of Irreversibility And Uncertainty On Capital Accumulation," Journal Of Monetary Economics_44 (December 1999), 339-378. 2001).

Acemoglu, Daron, “Labor- And Capital-Augmenting Technical Change,” M.I.T. (July

Arrow, Kenneth J., Chenery, Hollis B., Minhas, Bagicha S., and Solow, Robert M., "Capital-Labor Substitution and Economic Efficiency," The Review Of Economics And Statistics 43 (1961), 225-250; reprinted in Production and Capital: Collected Papers of Kenneth J. Arrow Vol. 5 (Cambridge: Harvard University Press, 1985), 50-103.

Ballard, Charles, L., Fullerton, Don, Shoven, John B., and Whalley, John, A General Equilibrium Model for Tax Policy Evaluation (Chicago: University of Chicago Press (for the NBER), 1985). Hill, 1995).

Barro, Robert J., and Sala-i-Martin, Xavier, Economic Growth (New York: McGraw-

Baxter, Marianne, and King, Robert G., "Measuring Business Cycles: Approximate Band-Pass Filters for Economic Time Series," The Review of Economics and Statistics 81 (November 1999), 575-593.

Berndt, Ernst R., "Reconciling Alternative Estimates of the Elasticity of Substitution," The Review of Economics and Statistics 63 (February 1976), 59-68.

Caballero, Ricardo J., "Small Sample Bias And Adjustment Costs," The Review Of Economics And Statistics 76 (February 1994), 52-58.

Caballero, Ricardo J., “Aggregate Investment,” in John B. Taylor and Michael Woodford (eds.), Handbook Of Macroeconomics, Volume 1B (Amsterdam: Elsevier North-Holland), 1999), 813-862.

Caballero, Ricardo J., Engel, Eduardo M.R.A., and Haltiwanger, John C., "Plant-Level Adjustment and Aggregate Investment Dynamics," Brookings Papers on Economic Activity (1995:2), 1-54.

Chirinko, Robert S, "Business Fixed Investment: A Critical Survey of Modeling Strategies, Empirical Results, and Policy Implications," Journal of Economic Literature 31 (December 1993), 1875-1911.

Chirinko, Robert S., Fazzari, Steven M., and Meyer, Andrew P., "How Responsive Is Business Capital Formation To Its User Cost?: An Exploration With Micro Data," Journal of Public Economics 74 (October 1999), 53-80. 
Coen, Robert M., "Tax Policy and Investment Behavior: Comment," American Economic Review 59 (June 1969), 370-379.

Cummins, Jason G. and Hassett, Kevin A., "The Effects of Taxation on Investment: New Evidence From Firm Level Panel Data," National Tax Journal 45 (September 1992), 243-252.

Cummins, Jason G., Hassett, Kevin A., and Hubbard, R. Glenn, "A Reconsideration of Investment Behavior Using Tax Reforms as Natural Experiments," Brookings Papers on Economic Activity (1994:2), 1-60.

Cummins, Jason G., Hassett, Kevin A., and Hubbard, R. Glenn, "Tax Reforms and Investment: A Cross-Country Comparison," Journal of Public Economics 62 (1996), 237-273.

Eisner, Robert, "A Permanent Income Theory for Investment: Some Empirical Explorations," American Economic Review 57 (June 1967), 363-390.

Eisner, Robert, "Tax Policy and Investment Behavior: Comment," American Economic Review 59 (June 1969), 379-388.

Eisner, Robert, "Tax Policy and Investment Behavior: Further Comment," American Economic Review 60 (September 1970), 746-752.

Eisner, Robert, and Nadiri, M. Ishaq, "Investment Behavior and Neo-Classical Theory," The Review of Economics and Statistics 50 (August 1968), 369-382.

Eisner, Robert, and Nadiri, M. Ishaq, "Neoclassical Theory of Investment Behavior: A Comment," The Review of Economics and Statistics 52 (May 1970), 216-222.

Engen, Eric, Gravelle, Jane, and Smetters, Kent, "Dynamic Tax Models: Why They Do The Things They Do," National Tax Journal 50 (September 1997), 657-682.

Fazzari, Steven M., Hubbard, R. Glenn, and Petersen, Bruce C., "Investment-Cash Flow Sensitivities Are Useful: A Comment On Kaplan and Zingales," Quarterly Journal of Economics 115 (May 2000), 695-705.

Fox, Tyler, and Fullerton, Don, "The Irrelevance of Detail in a Computable General Equilibrium Model," Economic Letters 36 (March 1991), 67-70.

Garber, Steven, and Klepper, Steven, "Extending the Classical Normal Errors-inVariables Model," Econometrica 48 (September 1980), 1541-1546.

Goolsbee, Austan, "Investment Tax Incentives, Prices, and the Supply of Capital Goods," Quarterly Journal of Economics 93 (1998), 121-148. 
Goolsbee, Austan, "The Importance of Measurement Erron in the Cost of Capital," National Tax Journal 53 (June 2000), 215-228.

Hall, Robert, E., "Comment On 'Plant-Level Adjustment and Aggregate Investment Dynamics,'" Brookings Papers on Economic Activity (1995:2), 47-51.

Hall, Robert E., and Jorgenson, Dale W., "Tax Policy and Investment Behavior," American Economic Review 57 (June 1967), 391-414.

Hall, Robert E., and Jorgenson, Dale W., "Tax Policy and Investment Behavior: Reply and Further Results," American Economic Review 59 (June 1969), 388-401.

Hall, Robert E., and Jorgenson, Dale W., "Application of the Theory of Optimum Capital Accumulation," in Gary Fromm (ed.), Tax Incentives and Capital Spending (Washington: Brookings Institution, 1971), 9-60.

Hamermesh, Daniel S., and Pfann, Gerard A., "Adjustment Costs In Factor Demand," Journal Of Economic Literature 34 (September 1996), 1264-1292.

Harberger, Arnold C., "The Corporation Income Tax: An Empirical Assessment," in Tax Revision Compendium, Vol. 1 (Washington: House Committee on Ways and Means, $86^{\text {th }}$ Congress, First Session, 1959), 231-250.

Harberger, Arnold C., "The Incidence of the Corporation Income Tax," Journal of Political Economy 70 (June 1962), 215-240.

Harhoff, Dietmar, and Ramb, Fred, "Investment And Taxation In Germany -- Evidence From Firm-Level Panel Data," in Deutsche Bundesbank (ed.), Investing Today For The World Of Tommorrow: Studies On The Investment Process In Europe (Berlin: Springer-Verlag, 2001), 47-73.

Hassett, Kevin A., and Hubbard, R. Glenn, "Tax Policy and Investment," in Alan J. Auerbach, ed., Fiscal Policy: Lessons from Economic Research (Cambridge: MIT Press, 1997), 339-385.

Hassett, Kevin A., and Hubbard, R. Glenn, "Are Investment Incentives Blunted By Changes In Prices Of Capital Goods?," International Finance (October 1998), 103-125.

Hubbard, R. Glenn, "Capital-Market Imperfections and Investment," Journal of Economic Literature 36 (March 1998), 193-225.

Joint Committee on Taxation, Joint Committee On Taxation Tax Modeling Project And 1997 Tax Symposium Papers (Washington: U.S. Government Printing Office, 1997). 
Jorgenson, Dale W., "Capital Theory and Investment Behavior," American Economic Review 53 (May 1963), 247-259.

Kaplan, Steven N., and Zingales, Luigi, "Do Investment-Cash Flow Sensitivities Provide Useful Measures Of Finance Constraints?," Quarterly Journal Of Economics 112 (February 1997), 169-215.

Kaplan, Steven N., and Zingales, Luigi, "Investment-Cash Flow Sensitivities Are Not Valid Measures Of Financing Constraints," Quarterly Journal Of Economics 115 (May 2000), 707-712.

Kiyotaki, Nobuhiro and West, Kenneth D, "Business Fixed Investment and the Recent Business Cycle in Japan," in Ben S. Bernanke and Julio J. Rotemberg (eds.), NBER

Macroeconomics Annual 1996 (Cambridge: MIT Press, 1996), 277-344.

Klump, Rainer, and Preissler, Harald, "CES Production Functions and Economic Growth,” Scandinavian Journal of Economics 102 (March 2000), 41-56.

Lucas, Robert E., Jr., "Labor-Capital Substitution in U.S. Manufacturing," in Arnold C. Harberger (ed.), The Taxation of Income from Capital (Washington: Brookings Institution, 1969), 223-274.

Mairesse, Jacques, Hall, Bronwyn H., and Mulkay, Benoit, "Firm-Level Investment In France And The United States: An Exploration Of What We Have Learned In Twenty Years," Annales d'Economie et Statistiques 55-56 (1999), 27-67.

Mankiw, N. Gregory, “The Growth Of Nations,” Brookings Papers On Economic Activity (1995:1), 275-310.

Miyagiwa, Kaz and Papageorgiou, Chris, "Elasticity Of Substitution And Growth: Normalized CES In The Diamond Model,” Economic Theory 21 (January 2003), 155-165.

Pitchford, John D., "Growth And The Elasticity Of Substitution," Economic Record 36 (December 1960), 491504.

Rao, Potluri, "Some Notes On The Errors-In-Variables Model," The American Statistician 27 (December 1973), 217-218.

Roeger, Werner, Veld, Jan in 't, and Woehrmann, Don I. Asoka, "Some Equity and Efficiency Considerations of International Tax Competition," European Commission (August 2000). 
Salinger, Michael A., and Summers, Lawrence H., "Tax Reform and Corporate Investment: A Microeconomic Simulation Study," in Martin S. Feldstein (ed.), Behavioral Simulation Methods in Tax Policy Analysis (Chicago: University of Chicago Press (for the NBER), 1983), 247-273.

Sargent, Thomas J., Macroeconomic Theory (New York: Academic Press, 1979).

Shapiro, Matthew D., "The Dynamic Demand For Labor and Capital," Quarterly Journal of Economics 101 (August 1986a), 513-542.

Shapiro, Matthew D., "Investment, Output, and the Cost of Capital," Brookings Papers on Economic Activity (1986:1b), 111-152.

Shea, John, "Instrument Relevance in Multivariate Linear Models: A Simple Measure," The Review of Economics and Statistics 79 (May 1997), 348-352.

Stock, James H., and Watson, Mark W., "A Simple MLE of Cointegrating Vectors in Higher Order Integrated Systems," Econometrica 61 (July 1993), 783-820.

Summers, Lawrence H., "Comment: 'Will 'The' Neoclassical Model of Investment Please Rise?: The General Structure of Investment Models and Their Implications for Tax Policy,"' in Jack M. Mintz and Douglas D. Purvis (eds.), The Impact of Taxation on Business Investment (Kingston, Ontario: John Deutsch Institute for the Study of Economic Policy, Queen's University, 1988), 171-173.

Whelan, Karl, “Tax Incentives, Material Inputs, And The Supply Curve For Capital Equipment," Board of Governors (May 1999).

\section{Appendix A: Trending Variables}

This appendix considers the effects of trending variables on the specification of the model. We begin with the following decomposition for variable $\mathrm{W}_{\mathrm{f}, \tau, \mathrm{t}}$ into non-growth (ng) and growth (g) components, where $\mathrm{W}$ corresponds to any of the model variables, $\mathrm{K}, \mathrm{Y}$, or $\mathrm{C}$ (note that, unlike in the text, we explicitly include an index for the $\tau$ interval even when it is redundant), 
$(A-1) \mathrm{W}_{\mathrm{f}, \tau, \mathrm{t}} \equiv \mathrm{W}_{\mathrm{f}, \tau, \mathrm{t}}^{\mathrm{ng}}+\mathrm{W}_{\mathrm{f}, \tau, \mathrm{t}}^{\mathrm{g}}$,

$$
\begin{gathered}
\mathrm{W}_{\mathrm{f}, \tau, \mathrm{t}}^{\mathrm{ng}} \equiv \mu_{\mathrm{f}, \tau}^{\mathrm{ng}}+v_{\mathrm{f}, \tau, \mathrm{t}}^{\mathrm{ng}}, \\
\mu_{\mathrm{f}, \tau}^{\mathrm{ng}}=\sum_{\mathrm{t}=1} \mathrm{~W}_{\mathrm{f}, \tau, \mathrm{t}}^{\mathrm{ng}} / \mathrm{T}_{\tau}, \\
\mathrm{T}_{\tau} \mathrm{T}_{\tau}{ }^{\mathrm{ng}}{ }_{\mathrm{f}, \tau, \mathrm{t}} / \mathrm{T}_{\tau}=0,
\end{gathered}
$$

$$
\mathrm{W}_{\mathrm{f}, \tau, \mathrm{t}}^{\mathrm{g}} \equiv \mu_{\mathrm{f}, \tau}^{\mathrm{ng}}\left[\left(1+\mathrm{g}_{\mathrm{f}}\right)^{\mathrm{t}}-1\right]
$$

In (A-2), the non-growth component equals the mean over the $\tau$ interval $\left(\mu_{\mathrm{f}, \tau}^{\mathrm{ng}}\right)$ and a deviation from the mean value $\left(v_{f, \tau, t}\right)$ that averages to zero. These summations are over all $\mathrm{T}_{\tau}$ time periods that are in the $\tau$ interval. In (A-3), the growth component is proportional to the mean, and increases at a firm-specific rate of $g_{f}$.

As in Section II, we measure the long-run value of $\mathrm{W}\left(\mathrm{W}_{\mathrm{f}, \mathrm{t}}\right)$ as a timeaverage over a $\tau$ interval $\left(\mathrm{W}_{\mathrm{f}, \tau}\right)$,

$(\mathrm{A}-4) \mathrm{W}_{\mathrm{f}, \mathrm{t}}^{*}=\mathrm{W}_{\mathrm{f}, \tau}$

$$
\begin{aligned}
& \mathrm{T}_{\tau} \\
= & \sum_{\mathrm{t}=1} \mathrm{~W}_{\mathrm{f}, \tau, \mathrm{t}} / \mathrm{T}_{\tau}, \\
= & \sum_{\mathrm{t}=1}^{\mathrm{T}_{\tau}} \mathrm{W}_{\mathrm{f}, \tau, \mathrm{t}}^{\mathrm{ng}} / \mathrm{T}_{\tau}+\sum_{\mathrm{t}=1}^{\mathrm{T}_{\tau}} \mathrm{W}_{\mathrm{f}, \tau, \mathrm{t}}^{\mathrm{g}} / \mathrm{T}_{\tau}, \\
= & \mu_{\mathrm{f}, \tau}^{\mathrm{ng}}+\sum_{\mathrm{t}=1} v_{\mathrm{f}, \tau, \mathrm{t}}^{\mathrm{ng}} / \mathrm{T}_{\tau}+\sum_{\mathrm{t}=1}^{\mathrm{T}_{\tau}} \mu_{\mathrm{f}, \tau}^{\mathrm{ng}}\left[\left(1+\mathrm{g}_{\mathrm{f}}\right)^{\mathrm{t}}-1\right] / \mathrm{T}_{\tau},
\end{aligned}
$$




$$
\begin{aligned}
& =\mu_{\mathrm{f}, \tau}^{\mathrm{ng}}+0+\mu_{\mathrm{f}, \tau}^{\mathrm{ng}} \sum_{\mathrm{t}=1}^{\mathrm{T}_{\tau}}\left[\left(1+\mathrm{g}_{\mathrm{f}}\right)^{\mathrm{t}}-1\right] / \mathrm{T}_{\tau}, \\
& =\mu_{\mathrm{f}, \tau}^{\mathrm{ng}} * \mathrm{H}\left[\mathrm{g}_{\mathrm{f}}\right], \\
& \mathrm{H}\left[\mathrm{g}_{\mathrm{f}}\right] \equiv 1+\sum_{\mathrm{t}=1}^{\mathrm{T}_{\tau}\left[\left(1+\mathrm{g}_{\mathrm{f}}\right)^{\mathrm{t}}-1\right] / \mathrm{T}_{\tau},}
\end{aligned}
$$

Our estimator (7) uses the difference between the $\tau=2$ and $\tau=1$ intervals in the logarithms of $\mathrm{W}_{\mathrm{f}, \tau}$,

$$
\begin{aligned}
(\mathrm{A}-5) \operatorname{Ln}\left\{\mathrm{W}_{\mathrm{f}, \tau=2}\right\}-\operatorname{Ln}\left\{\mathrm{W}_{\mathrm{f}, \tau=1}\right\}= & \operatorname{Ln}\left\{\mu_{\mathrm{f}, \tau=2\}}^{\mathrm{ng}}+\operatorname{Ln}\left\{\mathrm{H}\left[\mathrm{g}_{\mathrm{f}}\right]\right\}\right. \\
& -\operatorname{Ln}\left\{\mu_{\mathrm{f}, \tau=1}\right\}-\operatorname{Ln}\left\{\mathrm{H}\left[\mathrm{g}_{\mathrm{f}}\right]\right\}, \\
= & \operatorname{Ln}\left\{\mu_{\mathrm{f}, \tau=2}^{\mathrm{ng}} / \mu_{\mathrm{f}, \tau=1}^{\mathrm{ng}}\right\},
\end{aligned}
$$

which is the percentage change in the non-growth component of $\mathrm{W}_{\mathrm{f}, \tau}$. Thus, the variables entering the regression are not distorted by firm-specific growth.

\section{Appendix B: The Replacement Value of Capital}

The capital stock is a key variable in this study, and this appendix provides details about how we overcome several significant problems in measuring the capital stock from accounting data. The obvious proxies for the capital stock in the Compustat data, book values of gross or net property, plant, and equipment, are not acceptable measures of the economic value of the capital stock for two reasons. First, they value assets at the historical cost prevailing when the assets were acquired and therefore contain a mix of historical price levels that cannot be easily adjusted for inflation. Second, accounting depreciation rules likely do not capture economic depreciation correctly. The iterative "perpetual inventory" algorithm described here addresses these problems.

The first step in our procedure is to choose a seed value for the iteration. We use the nominal book value of net property, plant, and equipment for firm $\mathrm{f}$ from its first observation in the data set $\left(\mathrm{NPLANT}_{\mathrm{f}, 0}\right)$. To convert this value to real terms we employ data on the share of different kinds of capital assets (indexed by 
j) in the firm's two-digit SIC industry i. Denote this share as $\alpha_{\mathrm{i}, \mathrm{j}}$. The amount of capital $\left(\alpha_{i, j} N_{N L A N T}, 0\right)$ should be deflated by the asset-specific price index $p_{j, 0}$. Then the real seed value of the capital stock $\left(\mathrm{K}_{\mathrm{f}, 0}\right)$ is defined as:

$$
K_{f, 0}=\sum_{j} \frac{\alpha_{i, j} N P L A N T_{f, 0}}{p_{j, 0}} .
$$

Starting from this seed value, the remainder of the capital stock for firm $\mathrm{k}$ is constructed iteratively from:

$$
K_{f, t+1}=K_{f, t} \sum_{j} \alpha_{i, j}\left(1-\delta_{j}\right)+K C H G_{f, t} \sum_{j} \frac{\alpha_{i, j}\left(1-\delta_{j}\right)}{p_{j, t}} .
$$

The first term in equation (B-2) is the depreciated value of the period $t$ capital stock that remains in period $\mathrm{t}+1$. The depreciation rate $\delta_{\mathrm{j}}$ for each asset $\mathrm{j}$ is determined by DRI from the "double declining balance" formula:

$$
\delta_{j}=1-e^{-2 / L I F E_{j}},
$$

where $\mathrm{LIFE}_{\mathrm{j}}$ represents the estimated average service life for capital asset $\mathrm{j}$. The second term in equation (B-2) represents the addition (or deletion) to the period $t+1$ capital stock accounted for by new investment, acquisitions, or divestitures in period t. The variable $\mathrm{KCHG}_{\mathrm{f}, \mathrm{t}}$ (discussed in detail below) represents the nominal addition (or subtraction) of new capital goods for firm $\mathrm{f}$ in period $\mathrm{t}$ prices. The deflation method for $\mathrm{KCHG}_{\mathrm{f}, \mathrm{t}}$ is the same as for the seed value in equation (B1). We assume that new capital is acquired at the beginning of period $t$ and depreciates one full year before entering the period $t+1$ capital stock. (We also constructed capital stock series using a half year's depreciation for KCHG and found that it had only a trivial impact on the results.) If a firm adds to its capital stock in period $t$ only through conventional capital spending, the $\mathrm{KCHG}_{\mathrm{f}, \mathrm{t}}$ variable in equation (B-2) would equal the firm's investment $\left(\mathrm{I}_{\mathrm{f}, \mathrm{t}}\right)$, that we obtain from Compustat's capital expenditure data in the sources and uses of funds statement. In practice, acquisitions and divestitures can augment and deplete the capital stock independent of reported investment. Many panel studies delete firms with substantial acquisitions or divestitures. However, there are a large number of observations with acquisitions and divestitures in the Compustat data. Deleting these observations reduces the sample size and could induce a selection bias. We therefore develop a method to account for acquisitions and divestitures when 
constructing the capital stock data. (To the extent that acquisitions or divestitures create outliers in the data, these should be captured by our outlier detection algorithm described in Section III.)

The capital change variable $\left(\mathrm{KCHG}_{\mathrm{f}, \mathrm{t}}\right)$ in equation $(\mathrm{B}-2)$ is defined in a way that accounts for large acquisitions and divestitures. We appeal to the following accounting identities to derive a formula for $\mathrm{KCHG}_{\mathrm{f}, \mathrm{t}}$ :

$$
\begin{aligned}
& \Delta \operatorname{SPLANT}_{f, t}=I_{f, t}+\operatorname{ACQUIS}_{f, t}-\operatorname{RETIRE}_{f, t} \\
& \Delta \operatorname{NPLANT}_{f, t}=I_{f, t}+\operatorname{ACQUIS}_{f, t}-\operatorname{DEPR}_{f, t}
\end{aligned}
$$

$\triangle G P L A N T_{f, t}=\quad$ the change in gross plant and equipment from the end of year $\mathrm{t}-1$ to the end of year t;

$\triangle N P L A N T_{f, t}=\quad$ the change in net plant and equipment from the end of year $t-1$ to the end of year $t$;

$A_{C Q U I S}, t=$ acquisitions in year $\mathrm{t}$;

$\operatorname{RETIRE}_{f, t}=$ retirements in year $\mathrm{t},{ }^{27}$ and

$D E P R_{f, t} \quad=\quad$ accounting depreciation in year $\mathrm{t}$.

In the event of an acquisition, $\mathrm{KCHG}_{\mathrm{f}, \mathrm{t}}$ equals $\mathrm{I}_{\mathrm{f}, \mathrm{t}}+\mathrm{ACQUIS}_{\mathrm{f}, \mathrm{t}}$. Because Compustat does not have reliable figures for $\mathrm{ACQUIS}_{\mathrm{f}, \mathrm{t}}$, we rearrange equation (B4) to obtain:

$$
\begin{aligned}
& I_{f, t}+\operatorname{ACQUIS}_{f, t}=\Delta \operatorname{GPLANT}_{f, t}+\operatorname{RETIRE}_{f, t} \text { or } \\
& \operatorname{KCHG}_{f, t}=\Delta \operatorname{GPANT}_{f, t}+\operatorname{RETIRE}_{f, t}
\end{aligned}
$$

In the event of a divestiture, we want to decrease the capital stock by the depreciated value of the capital sold. In this case:

$$
K C H G_{f, t}=\Delta N P L A N T_{f, t}
$$

If there is no major acquisition or divestiture, then we retain the basic formula:

\footnotetext{
${ }^{27}$ Compustat defines retirements as "a deduction from a company's property, plant, and equipment account resulting from the retirement of obsolete or damaged goods and/or physical structures."
} 


$$
K C H G_{f, t}=I_{f, t}
$$

We now need an empirical test to determine whether a firm has undergone an acquisition or divestiture in a given year. There are two rules of thumb that aid us in this search. First, $\triangle$ GPLANT $_{\mathrm{f}, \mathrm{t}}$ is normally less than $\mathrm{I}_{\mathrm{f}, \mathrm{t}}$ because of retirements. Therefore, if $\Delta$ GPLANT $_{\mathrm{f}, \mathrm{t}}>\mathrm{I}_{\mathrm{f}, \mathrm{t}}$ by a substantial amount, it signals an acquisition with a high probability. Second, $\Delta \mathrm{GPLANT}_{\mathrm{f}, \mathrm{t}}$ is normally greater than RETIRE $_{\mathrm{f}, \mathrm{t}}$ because retirements are the only way to reduce gross plant and equipment in the absence of a divestiture. Therefore, if $\Delta$ GPLANT $_{\mathrm{f}, \mathrm{t}}<\mathrm{RETIRE}_{\mathrm{f}, \mathrm{t}}$ by a substantial amount it signals a divestiture.

We define a "substantial" amount as a discrepancy of ten percent or more. The point of imposing the ten percent limit is to make acquisition and divestiture adjustments conservative. That is, we only deviate from the standard formula when there is clear evidence that this formula is misleading. In this case, if

$$
\frac{\Delta \operatorname{GPLANT}_{f, t}-I_{f, t}}{\operatorname{GPLANT}_{f, t-1}}>0.1,
$$

then we assume an acquisition and define $\mathrm{KCHG}_{\mathrm{f}, \mathrm{t}}$ from equation (B-6). In contrast, if

$$
\frac{\Delta \operatorname{GPLANT}_{f, t}+\operatorname{RETIRE}_{f, t}}{\operatorname{GPLANT}_{f, t-1}}<-0.1,
$$

then we assume a divestiture and define $\mathrm{KCHG}_{\mathrm{f}, \mathrm{t}}$ from equation (B-7). If neither rule holds, we simply define $\mathrm{KCHG}_{\mathrm{f}, \mathrm{t}}$ as investment spending, as in equation (B-8).

\section{Appendix C: Short-Run Frictions and Measurement Error}

This appendix relaxes the assumption that the long-run values of capital and output appearing in the model of Section II can be measured without error as timeaverages over a $\tau$ interval -- $\Sigma_{\mathrm{t}} \mathrm{K}_{\mathrm{f}, \tau, t} / \mathrm{T}_{\tau} \equiv \mathrm{K}_{\mathrm{f}, \tau}=\mathrm{K}_{\mathrm{f}, \mathrm{t}}$ and $\Sigma_{\mathrm{t}} \mathrm{Y}_{\mathrm{f}, \tau, \mathrm{t}} / \mathrm{T}_{\tau} \equiv \mathrm{Y}_{\mathrm{f}, \tau}=\mathrm{Y}_{\mathrm{f}, \mathrm{t}}$ for $\mathrm{t}=1, \mathrm{~T}_{\tau}$. (Note that, unlike in the text but as in Appendix A, we explicitly include an index for the $\tau$ interval even when it is redundant.) In particular, these equalities might be disrupted if short-run frictions affect long-run values. For example, a firm facing irreversibility constraints will exhibit a reluctance to invest that lowers its optimal capital stock. In this case, a negative, firm-specific measurement error 
drives a wedge between $\mathrm{K}_{\mathrm{f}, \tau}$ and $\mathrm{K}_{\mathrm{f}, \mathrm{t}}$ and, through the production function, a wedge between $\mathrm{Y}_{\mathrm{f}, \tau}$ and $\mathrm{Y}_{\mathrm{f}, \mathrm{t}}$. However, the same set of constraints create a "hangover effect," as a firm occasionally finds itself with capital that it would like to dispose of but can not due to irreversibility constraints. Thus, the long-run capital stock for a firm facing irreversibility frictions can be greater than or less than the long-run capital stock for a frictionless firm (Abel and Eberly, 1999). An additional friction is introduced by asymmetric adjustment costs implying that the average values of capital and output will differ in general from their long-run values.

These considerations introduce measurement error $\left(\mathrm{MEK}_{\mathrm{f}, \tau}\right)$ that drives a wedge between $K_{f, \tau}$ and $K_{f, t}^{*}$ (a similar analysis applies to $\mathrm{Y}_{\mathrm{f}, \tau}$ and $\mathrm{Y}_{\mathrm{f}, \mathrm{t}}$ ),

$$
\mathrm{K}_{\mathrm{f}, \tau}=\mathrm{K}_{\mathrm{f}, \mathrm{t}}+\mathrm{MEK}_{\mathrm{f}, \tau}
$$

We assume that the measurement error between $\mathrm{K}_{\mathrm{f}, \tau}$ and $\mathrm{K}_{\mathrm{f}, \mathrm{t}}$ increases with the size of the "true" long-run capital stock and that $\mathrm{MEK}_{\mathrm{f}, \tau}=\mathrm{Mf}, \tau_{\mathrm{f}} \mathrm{K}_{\mathrm{f}, \mathrm{t}}$. Furthermore, $\mathrm{M}_{\mathrm{f}, \tau}$ consists of two components, $\mathrm{m}_{\mathrm{f}}$ and $\mathrm{m}_{\mathrm{f}, \tau}$, representing measurement error that varies by firm and by firm and interval, respectively. Combined with $(\mathrm{C}-1)$, these assumptions generate the following model of measurement error,

(C-2a) $\quad \mathrm{K}_{\mathrm{f}, \tau}=\mathrm{K}_{\mathrm{f}, \mathrm{t}} \mathrm{Mf}, \tau_{\mathrm{f}}$

$(\mathrm{C}-2 \mathrm{~b}) \quad \mathrm{Mf}, \tau_{\mathrm{f}}=1+\mathrm{m}_{\mathrm{f}}+\mathrm{m}_{\mathrm{f}, \tau}$

To understand the impact of measurement error on our estimating equation, we analyze $(\mathrm{C}-2)$ in conjunction with the trending variables analyzed in Appendix A. We begin with $\mathrm{K}_{\mathrm{f}, \mathrm{t}}=\mathrm{K}_{\mathrm{f}, \tau} / \mathrm{Mf}_{\mathrm{f}, \tau}$, and thus divide the right-side of (A-4) by $\mathrm{Mf}, \tau_{\mathrm{f}}$. Since $\mathrm{Mf}_{\mathrm{f} \tau}$ is indexed by $\tau$, it passes through the summation sign, and the version of (A-4) accounting for measurement error and trending variables is as follows,

$$
\mathrm{K}_{\mathrm{f}, \mathrm{t}}=\mu_{\mathrm{f}, \tau}^{\mathrm{ng}} * \mathrm{H}\left[\mathrm{g}_{\mathrm{f}}\right] / \mathrm{Mf}_{\mathrm{f}, \tau}
$$

where $\mu_{f, \tau}^{n g}$ is the mean of the non-growth component of $\mathrm{K}_{\mathrm{f}, \tau}$ and $\mathrm{H}\left[\mathrm{g}_{\mathrm{f}}\right]$ is a function of the firm-specific growth rate. See Appendix A for details. 
Our estimator replaces the logarithm of $\mathrm{K}_{\mathrm{f}, \mathrm{t}}$ in (4) with the logarithm of the expression in (C-3), and differences the resulting equation between the $\tau=2$ and $\tau=1$ intervals,

$$
\begin{aligned}
(\mathrm{C}-4) \operatorname{Ln}\left\{\mathrm{K}_{\mathrm{f}, \tau=2} / \mathrm{Mf}_{\mathrm{f}, \tau=2}\right\}-\operatorname{Ln}\left\{\mathrm{K}_{\mathrm{f}, \tau=1} / \mathrm{M}_{\mathrm{f}, \tau=1}\right\} \\
=\operatorname{Ln}\left\{\mu_{\mathrm{f}, \tau=2}^{\mathrm{ng}}\right\}+\operatorname{Ln}\left\{\mathrm{H}\left[\mathrm{g}_{\mathrm{f}}\right]\right\}-\operatorname{Ln}\left\{\mu_{\mathrm{f}, \tau=1}^{\mathrm{ng}}\right\}-\operatorname{Ln}\left\{\mathrm{H}\left[\mathrm{g}_{\mathrm{f}}\right]\right\} \\
\quad+\left(\mathrm{m}_{\mathrm{f}}+\mathrm{m}_{\mathrm{f}, \tau=2)}-\left(\mathrm{m}_{\mathrm{f}}+\mathrm{m}_{\mathrm{f}, \tau=1}\right),\right. \\
=\operatorname{Ln}\left\{\mu^{\mathrm{ng}, \tau=2} / \mu_{\mathrm{f}, \tau=1}^{\mathrm{ng}}\right\}-\Delta \mathrm{m}_{\mathrm{f}, \tau},
\end{aligned}
$$

which is identical to (A-5) in Appendix A with the addition of $-\Delta \mathrm{m}_{\mathrm{f}, \tau}$. Note the firm-specific component of the measurement error $\left(\mathrm{m}_{\mathrm{f}}\right)$ cancels in the first difference.

The additional term, $-\Delta \mathrm{m}_{\mathrm{f}, \tau}$, can be incorporated straightforwardly into the econometric model. The error term in (7) is composed of a productivity shock, $-\Delta \mathrm{w}_{\mathrm{f}, \tau}$, that is firm-specific and interval-specific and, to reflect the effects of measurement error, it can be replaced by the composite error, $-\left(\Delta \mathrm{W}_{\mathrm{f}, \tau}+\Delta \mathrm{m}_{\mathrm{f}, \tau}\right)$. Note that the two components both vary by firm and interval. We expect the impact of $\Delta \mathrm{m}_{\mathrm{f}, \tau}$ to be relatively small because firm and industry effects have already been removed.

In the event that there is some correlation between $\Delta \mathrm{m}_{\mathrm{f}, \tau}$ and the regressors induced by measurement error, the estimated $\sigma$ will be attenuated, that is, closer to zero than the "true" $\sigma$. Since the measurement error considered in this Appendix does not affect the user cost variable directly, the effect on $\sigma$ is indirect, and equals the product of the attenuation of the coefficient on output and a coefficient representing the correlation between "true" sales growth and "true" user cost growth (Garber and Klepper, 1980, equation (2.6)). The quantitative impact of this type of measurement error is assessed in Section IV.C (the Rao test). Furthermore, since this type of measurement error applies only to capital and output, it will not impact the estimate of $\sigma$ in the regression in the third column of Table $2(\eta=1)$ with the growth rate of the capital-output ratio as the dependent variable. This estimate of $\sigma$ and the Rao test both suggest that the type of measurement error considered in this Appendix is quantitatively unimportant. 


\section{CESifo Working Paper Series}

(for full list see www.cesifo.de)

1175 Chang Woon Nam and Doina Maria Radulescu, Types of Tax Concessions for Attracting Foreign Direct Investment in Free Economic Zones, April 2004

1176 M. Hashem Pesaran and Andreas Pick, Econometric Issues in the Analysis of Contagion, April 2004

1177 Steinar Holden and Fredrik Wulfsberg, Downward Nominal Wage Rigidity in Europe, April 2004

1178 Stefan Lachenmaier and Ludger Woessmann, Does Innovation Cause Exports? Evidence from Exogenous Innovation Impulses and Obstacles, April 2004

1179 Thiess Buettner and Johannes Rincke, Labor Market Effects of Economic Integration The Impact of Re-Unification in German Border Regions, April 2004

1180 Marko Koethenbuerger, Leviathans, Federal Transfers, and the Cartelization Hypothesis, April 2004

1181 Michael Hoel, Tor Iversen, Tore Nilssen, and Jon Vislie, Genetic Testing and Repulsion from Chance, April 2004

1182 Paul De Grauwe and Gunther Schnabl, Exchange Rate Regimes and Macroeconomic Stability in Central and Eastern Europe, April 2004

1183 Arjan M. Lejour and Ruud A. de Mooij, Turkish Delight - Does Turkey's accession to the EU bring economic benefits?, May 2004

1184 Anzelika Zaiceva, Implications of EU Accession for International Migration: An Assessment of Potential Migration Pressure, May 2004

1185 Udo Kreickemeier, Fair Wages and Human Capital Accumulation in a Global Economy, May 2004

1186 Jean-Pierre Ponssard, Rent Dissipation in Repeated Entry Games: Some New Results, May 2004

1187 Pablo Arocena, Privatisation Policy in Spain: Stuck Between Liberalisation and the Protection of Nationals' Interests, May 2004

1188 Günter Knieps, Privatisation of Network Industries in Germany: A Disaggregated Approach, May 2004

1189 Robert J. Gary-Bobo and Alain Trannoy, Efficient Tuition Fees, Examinations, and Subsidies, May 2004 
1190 Saku Aura and Gregory D. Hess, What's in a Name?, May 2004

1191 Sjur Didrik Flåm and Yuri Ermoliev, Investment Uncertainty, and Production Games, May 2004

1192 Yin-Wong Cheung and Jude Yuen, The Suitability of a Greater China Currency Union, May 2004

1193 Inés Macho-Stadler and David Pérez-Castrillo, Optimal Enforcement Policy and Firms' Emissions and Compliance with Environmental Taxes, May 2004

1194 Paul De Grauwe and Marianna Grimaldi, Bubbles and Crashes in a Behavioural Finance Model, May 2004

1195 Michel Berne and Gérard Pogorel, Privatization Experiences in France, May 2004

1196 Andrea Galeotti and José Luis Moraga-González, A Model of Strategic Targeted Advertising, May 2004

1197 Hans Gersbach and Hans Haller, When Inefficiency Begets Efficiency, May 2004

1198 Saku Aura, Estate and Capital Gains Taxation: Efficiency and Political Economy Consideration, May 2004

1199 Sandra Waller and Jakob de Haan, Credibility and Transparency of Central Banks: New Results Based on Ifo's World Economicy Survey, May 2004

1200 Henk C. Kranendonk, Jan Bonenkamp, and Johan P. Verbruggen, A Leading Indicator for the Dutch Economy - Methodological and Empirical Revision of the CPB System, May 2004

1201 Michael Ehrmann, Firm Size and Monetary Policy Transmission - Evidence from German Business Survey Data, May 2004

1202 Thomas A. Knetsch, Evaluating the German Inventory Cycle - Using Data from the Ifo Business Survey, May 2004

1203 Stefan Mittnik and Peter Zadrozny, Forecasting Quarterly German GDP at Monthly Intervals Using Monthly IFO Business Conditions Data, May 2004

1204 Elmer Sterken, The Role of the IFO Business Climate Indicator and Asset Prices in German Monetary Policy, May 2004

1205 Jan Jacobs and Jan-Egbert Sturm, Do Ifo Indicators Help Explain Revisions in German Industrial Production?, May 2004

1206 Ulrich Woitek, Real Wages and Business Cycle Asymmetries, May 2004

1207 Burkhard Heer and Alfred Maußner, Computation of Business Cycle Models: A Comparison of Numerical Methods, June 2004 
1208 Costas Hadjiyiannis, Panos Hatzipanayotou, and Michael S. Michael, Pollution and Capital Tax Competition within a Regional Block, June 2004

1209 Stephan Klasen and Thorsten Nestmann, Population, Population Density, and Technological Change, June 2004

1210 Wolfgang Ochel, Welfare Time Limits in the United States - Experiences with a New Welfare-to-Work Approach, June 2004

1211 Luis H. R. Alvarez and Erkki Koskela, Taxation and Rotation Age under Stochastic Forest Stand Value, June 2004

1212 Bernard M. S. van Praag, The Connexion Between Old and New Approaches to Financial Satisfaction, June 2004

1213 Hendrik Hakenes and Martin Peitz, Selling Reputation When Going out of Business, June 2004

1214 Heikki Oksanen, Public Pensions in the National Accounts and Public Finance Targets, June 2004

1215 Ernst Fehr, Alexander Klein, and Klaus M. Schmidt, Contracts, Fairness, and Incentives, June 2004

1216 Amihai Glazer, Vesa Kanniainen, and Panu Poutvaara, Initial Luck, Status-Seeking and Snowballs Lead to Corporate Success and Failure, June 2004

1217 Bum J. Kim and Harris Schlesinger, Adverse Selection in an Insurance Market with Government-Guaranteed Subsistence Levels, June 2004

1218 Armin Falk, Charitable Giving as a Gift Exchange - Evidence from a Field Experiment, June 2004

1219 Rainer Niemann, Asymmetric Taxation and Cross-Border Investment Decisions, June 2004

1220 Christian Holzner, Volker Meier, and Martin Werding, Time Limits on Welfare Use under Involuntary Unemployment, June 2004

1221 Michiel Evers, Ruud A. de Mooij, and Herman R. J. Vollebergh, Tax Competition under Minimum Rates: The Case of European Diesel Excises, June 2004

1222 S. Brock Blomberg and Gregory D. Hess, How Much Does Violence Tax Trade?, June 2004

1223 Josse Delfgaauw and Robert Dur, Incentives and Workers' Motivation in the Public Sector, June 2004

1224 Paul De Grauwe and Cláudia Costa Storti, The Effects of Monetary Policy: A MetaAnalysis, June 2004 
1225 Volker Grossmann, How to Promote R\&D-based Growth? Public Education Expenditure on Scientists and Engineers versus R\&D Subsidies, June 2004

1226 Bart Cockx and Jean Ries, The Exhaustion of Unemployment Benefits in Belgium. Does it Enhance the Probability of Employment?, June 2004

1227 Bertil Holmlund, Sickness Absence and Search Unemployment, June 2004

1228 Klaas J. Beniers and Robert Dur, Politicians' Motivation, Political Culture, and Electoral Competition, June 2004

1229 M. Hashem Pesaran, General Diagnostic Tests for Cross Section Dependence in Panels, July 2004

1230 Wladimir Raymond, Pierre Mohnen, Franz Palm, and Sybrand Schim van der Loeff, An Empirically-Based Taxonomy of Dutch Manufacturing: Innovation Policy Implications, July 2004

1231 Stefan Homburg, A New Approach to Optimal Commodity Taxation, July 2004

1232 Lorenzo Cappellari and Stephen P. Jenkins, Modelling Low Pay Transition Probabilities, Accounting for Panel Attrition, Non-Response, and Initial Conditions, July 2004

1233 Cheng Hsiao and M. Hashem Pesaran, Random Coefficient Panel Data Models, July 2004

1234 Frederick van der Ploeg, The Welfare State, Redistribution and the Economy, Reciprocal Altruism, Consumer Rivalry and Second Best, July 2004

1235 Thomas Fuchs and Ludger Woessmann, What Accounts for International Differences in Student Performance? A Re-Examination Using PISA Data, July 2004

1236 Pascalis Raimondos-Møller and Alan D. Woodland, Measuring Tax Efficiency: A Tax Optimality Index, July 2004

1237 M. Hashem Pesaran, Davide Pettenuzzo, and Allan Timmermann, Forecasting Time Series Subject to Multiple Structural Breaks, July 2004

1238 Panu Poutvaara and Andreas Wagener, The Invisible Hand Plays Dice: Eventualities in Religious Markets, July 2004

1239 Eckhard Janeba, Moral Federalism, July 2004

1240 Robert S. Chirinko, Steven M. Fazzari, and Andrew P. Meyer, That Elusive Elasticity: A Long-Panel Approach to Estimating the Capital-Labor Substitution Elasticity, July 2004 